\title{
Review of risk from potential emerging contaminants in UK groundwater
}

Marianne Stuart ${ }^{\mathrm{a} *}$, Dan Lapworth ${ }^{\mathrm{a}}$, Emily Crane $^{\mathrm{a}}$, Alwyn Hart $^{\mathrm{b}}$

${ }^{\text {a }}$ British Geological Survey, Maclean Building, Wallingford, OX10 8BB, UK

${ }^{\mathrm{b}}$ Environment Agency, Olton Court, Solihull, B92 7HX, UK

*Corresponding author. Tel: +44 01491 692298, Fax: +44 01491692345

E mail address: mest@bgs.ac.uk

\begin{abstract}
This paper provides a review of the types of emerging organic groundwater contaminants (EGCs) which are beginning to be found in the UK. EGCs are compounds being found in groundwater that were previously not detectable or known to be significant and can come from agricultural, urban and rural point sources. EGCs include nanomaterials, pesticides, pharmaceuticals, industrial compounds, personal care products, fragrances, water treatment by-products, flame retardants and surfactants, as well as caffeine and nicotine. Many are relatively small polar molecules which may not be effectively removed by drinking water treatment. Data from the UK Environment Agency's groundwater screening programme for organic pollutants found within the 30 most frequently detected compounds a number of EGCs such as pesticide metabolites, caffeine and DEET. Specific determinands frequently detected include pesticides metabolites, pharmaceuticals including carbamazepine and triclosan, nicotine, food additives and alkyl phosphates. This paper discusses the routes by which these compounds enter groundwater, their toxicity and potential risks to drinking water and the environment. It identifies challenges that need to be met to minimise risk to drinking water and ecosystems.
\end{abstract}

\section{Keywords}

Emerging contaminants, groundwater, toxicity, risk assessment, pesticides, metabolites, pharmaceuticals, wastewater treatment 


\section{Introduction}

The term emerging groundwater contaminants (EGCs) is generally used to refer to compounds previously not considered or known to be significant in groundwater in terms of distribution and/or concentration, which are now being more widely detected and which have the potential to cause known or suspected adverse ecological or human health effects. Synthesis of new chemicals or changes in use and disposal of existing chemicals can create new sources of EGCs. These will also include substances that have long been present in the environment but whose presence and significance are only now being elucidated (Daughton, 2004). As analytical techniques improve, previously undetected organic micro-contaminants are being observed in the aqueous environment, e.g. metaldehyde. Richardson and Ternes (2011) review recent analytical developments in the emerging contaminant context.

EGCs are commonly derived from a variety of municipal, agricultural, and industrial sources and pathways. Many have remained unidentified presumably due to similar reasons to current, well-established problems. For example, Jackson (2004) ascribes the historical lack of recognition of chlorinated solvent contamination and its subsequent emergence to the lack of a technical paradigm explaining the processes of contamination and the identification of adverse effects.

Many EGCs remain unregulated and Kavanaugh (2003) set out the technical and institutional challenges presented by unregulated contaminants. The number of regulated contaminants will continue to grow slowly over the coming decades. In the European context groundwater quality is currently regulated under the Water Framework Directive and the Groundwater Daughter Directive and drinking water under the Drinking Water Directive. Pesticides are also regulated under the Plant Protection and Biocides Directives. Some of these contaminants can have human or ecological health effects and there is a need for better understanding of their fate in environmental systems.

The European Drinking Water Directive sets limits for a small number of organic micropollutants comprising aromatic hydrocarbons, chlorinated solvents and disinfection byproducts (EC, 1998). The Priority Substances Directive establishes a number of Priority Substances, including benzene, octyl and nonyl phenols, specified polyaromatic hydrocarbons (PAH), di(2-ethylhexyl)phthalate and a range of chlorinated hydrocarbons (EC, 2008). Proposed revisions include the emerging contaminants ibuprofen, diclofenac, $\alpha$ ethinyloestradiol, $\beta$-oestradiol and perfluorooctane sulfonate (PFOS) (EC, 2011). 
The US EPA have derived statutory guideline values for about 125 contaminants in drinking water of which 31 could be considered to be micro-organic pollutants excluding pesticides. None of these are pharmaceuticals or personal care products (PCP) (US EPA, 2010).

Most emerging contaminant research has focussed on surface waters as these are likely to contain greater concentrations of contaminants from sources such as wastewater treatment works' (WTWs) discharges. Surface water is also easier to monitor than groundwater in some respects. The approach taken in this review is that surface water data can be used to give us an idea of potential future groundwater problems and can provide an early warning.

This paper provides a review of the types of EGCs which are beginning to be found in groundwater of the UK. This is drawn primarily from UK and European studies, supplemented by work from the US. It discusses the routes by which these compounds enter groundwater, including resistance to wastewater treatment, their toxicity and the consequent potential risks posed to drinking water and the environment. This provides the context to a UK groundwater monitoring dataset. Challenges that need to be met to minimise risk are identified.

\section{Types of emerging groundwater contaminants}

From their sources, physical and chemical characteristics, mobility/behaviour in the aqueous environment and associated hazards the following types of micro-contaminants may be considered to be emerging in groundwater. The world-wide occurrence, sources and fate of a range of EGCs, including pharmaceuticals and personal care compounds in groundwater has been reviewed by Lapworth et al. (submitted).

Much more is known about pesticides in groundwater compared to other compounds, such as pharmaceuticals, which are more poorly characterised. The hazards to human health of some compounds are well documented, but their ability to travel through the aqueous environment is only just being investigated, and environmental persistence is as yet unknown.

\subsection{Pesticides}

Pesticides have been detected at trace concentrations in UK groundwater for a considerable period. As those compounds which pose the greatest threat to the environment are gradually withdrawn, e.g. atrazine in 1993, the compounds which are substituted can in turn lead to problems, e.g. diuron which is itself now banned. A number of compounds have recently 
caused problems as analytical methods have improved, for example metaldehyde (Bristol Water, 30/1/2009; Environment Agency, Jan 2010; Water UK, 2009). Attention has now also turned to pesticide metabolites, also termed degradates and reaction products (Kolpin et al., 1998). By their nature these compounds are biologically active and many may be toxic and such data forms part of the pesticide registration process. Studies have shown that pesticide metabolites are often detected in groundwater at higher concentrations compared to parent compounds from both agricultural and amenity use (Kolpin et al., 2004; Lapworth and Gooddy, 2006).

\subsection{Pharmaceuticals}

The presence of pharmaceutical chemicals in the aquatic environment has long been recognised as a concern (Richardson and Bowron, 1985). The primary routes for pharmaceuticals into the environment are through human excretion, disposal of unused products and through agricultural usage (Poynton and Vulpe, 2009). A wide range of pharmaceutical products have been detected in surface and groundwater, associated with wastewater disposal (Barnes et al., 2008; Miller and Meek, 2006; Nikolaou et al., 2007; Pérez and Barceló, 2007; Ternes and Hirsch, 2000; Vulliet and Cren-Olivé, 2011; Watkinson et al., 2009). These have included:

- veterinary and human antibiotics: e.g. ciprofloxacin, erythromycin, lincomycin, sulfamethoxazole, tetracycline

- other prescription drugs: codeine, salbutamol, carbamazepine

- non prescription drugs: acetaminophen (paracetamol), ibuprofen, salicylic acid

- iodinated X-ray contrast media: iopromide, iopamidol

Other potential threats to surface water which have been identified are tamiflu and chemotherapy drugs, such as 5-fluorourcil, ifosfamide or cyclophosphamide (Buerge et al., 2006; Johnson et al., 2008; Moldovan, 2006; Singer et al., 2007) and illicit drugs such as cocaine and amphetamines (Kasprzyk-Hordern et al., 2008; Zuccato et al., 2008).

\section{3 “Life-style compounds"}

Caffeine and nicotine, and the nicotine metabolite cotinine, are widely detected in groundwater impacted by sewage effluent (Godfrey et al., 2007; Seiler et al., 1999; Teijon et al., 2010). Van Stempvoort et al. (2011) found high concentrations of the artificial sweeteners 
acesulfame, saccharine, cyclamate and sucralose in groundwater impacted by sewage infiltration ponds and Buerge et al. (2009) showed acesulfame to be widely detected in the aquatic environment due to its use, mobility and persistence.

\subsection{Personal care}

Personal care compounds are commonly transmitted to the aqueous environment through WTWs. These have included:

- DEET - N,N-diethyl-meta-toluamide, the most common active ingredient in insect repellents

- parabens - alkyl esters of p-hydroxybenzoic acid, used since the 1930s as bacteriostatic and fungistatic agents in drugs, cosmetics, and foods

- bacteriocide and antifungal agents - triclosan is widely used in household products, such as toothpaste, soap and anti-microbial sprays

- polycyclic musks - tonalide and galaxolide are used as fragrances in a wide range of washing and cleaning agents and personal care products

- UV filters/sunscreen - organic filters include the benzophenones and methoxycinnamates

Lindström et al. (2002) detected triclosan and its metabolite methyl triclosan in surface water in Switzerland and considered the metabolite to be persistent.

Tonalide (AHTN), galaxolide (HHCB) and HHCB-lactone have been detected in WTW effluents (Horii et al., 2007). These compounds have been used as markers for wastewater in surface water (Buerge et al., 2003; Fromme et al., 2001). Heberer (2002a) discusses the results from investigations of synthetic musk concentrations found in sewage, sewage sludge, surface water, aquatic sediment, and biota samples in terms of bioaccumulation, metabolism in fish, and environmental and human risk assessment.

The majority of compounds used as sun screens are lipophilic, conjugated aromatic compounds, but are detected in the aqueous environment (Jeon et al., 2006).

\subsection{Industrial additives and by-products}

There are a wide range of industrial compounds which can be released to the environment. Many of these have led to well-established problems, such as the chlorinated solvents, petroleum hydrocarbons, including the polyaromatic hydrocarbons and the fuel oxygenate 
methyl tertiary-butyl ether, and plasticisers/resins bisphenols, adipates and phthalates (Garrett et al., 1986; Moran et al., 2005; Moran et al., 2006; Verliefde et al., 2007). Most of these industrial compounds are classed as priority pollutants or now have drinking water limits and as such are not emerging contaminants. However, some breakdown products may be regarded as emerging contaminants.

Industrial EGCs may include:

- 1,4-dioxane, a stabiliser used with 1,1,1,-trichloroethane which is highly soluble in groundwater, resistant to naturally occurring biodegradation processes., does not readily bind to soils, and readily leaches to groundwater (Abe, 1999). In 2008, testing, sponsored by an independent consumers organization, found 1,4-dioxane in almost half of tested personal-care products.

- Benzotriazole derivatives which are found in pharmaceuticals such as antifungal, antibacterial, and antihelmintic drugs. Benzotriazoles are persistent in the aqueous environment (Giger et al., 2006; Voutsa et al., 2006).

- Dioxins can be produced as a consequence of degradation of other micropollutants e.g. from the antimicrobial additive triclosan (ENDS, 2010; Mezcua et al., 2004).

\subsection{Food additives}

Triethyl citrate is used as a food additive to stabilise foams, e.g. egg white, and is also used in pharmaceutical coatings and as a plasticiser. Butylated hydroxyanisole (BHA) and butylated hydroxytoluene (BHT) are used to prevent fat spoilage in foods. Other food additives include camphor, 1,8-cineole (eucalyptol), citral, citronellal, cis-3-hexenol, heliotropin, hexanoic acid, menthol, phenylethyl alcohol, triacetin, and terpineol. Some of these may be implicated as oxidants or endocrine disruptors (Jobling et al., 1995).

\subsection{Water treatment by-products}

The trihalomethanes and haloacetic acids are well established by-products of water disinfection (Boorman, 1999). More recent concern has focused on N-nitrosodimethylamine (NDMA) as a drinking water contaminant resulting from reactions occurring during chlorination or via direct industrial contamination. Because of the relatively high concentrations of this the potent carcinogen formed during wastewater chlorination, the intentional and unintentional reuse of municipal wastewater is a particularly important area 
(Mitch et al., 2003). Richardson (2003) found that the change from disinfection with chlorine to ozone and chloramines can increase levels of other potentially toxic by-products, e.g. bromo- and iodo- THMs and brominated MX (3-chloro-4-dichloromethyl)-5-hydroxy-2(5H)furanone). Other by products of water treatment can include polyacrylamide and epichlohydrin.

\subsection{Flame/fire retardants}

Polybrominated diphenyl ether flame retardants are extensively used in resins for household and industrial use (Rahman et al., 2001) and may enter the environment via waste disposal to landfill and incineration. Phosphate-based retardants such tris-(2-chloroethyl) phosphate (TRCP) appear to work by forming a non-flammable barrier (Weil et al., 1996) are used in industrial and consumer products.

\subsection{Surfactants}

The priority pollutants octyl- and nonyl-phenol (OP and NP) are used in the production of alkyl phenol ethoxylates (APEs) which are used in the manufacture of surfactants. Both the parent ethoxylates and their metabolites, alkyl phenols and carboxylic degradation products, persist in the aquatic environment (Montgomery-Brown and Reinhard, 2003; Soares et al., 2008).

Perfluorinated sulfonates and carboxylic acids including perfluorooctane sulfonate (PFOS) and perfluorooctanoic acid (PFOA) have been used for over 50 years in food packaging and cookware coatings, paints and surfactants cosmetics and fire-fighting foams with consequent entry to the environment by run-off from sites of major fires (e.g. Buncefield, UK). They are found in WTW effluents and surface water and are very persistent in the environment (Ahrens et al., 2009; Poynton and Vulpe, 2009). Harada et al. (2003) showed PFOS to be present in sewage effluent in Japan and it has been detected in surface water in Japan (Harada et al., 2003; Saito et al., 2003).

Siloxanes are used in many personal care products and industrial coatings and there is concern about potential toxicity and transport into the environment (Richardson, 2007).

\subsection{Hormones and sterols}

Sex hormones include androgens, such as androstenedione and testosterone, and oestrogens such as oestrone, oestriol, $17 \alpha$ - and $17 \beta$-oestrodiol, and progesterone. There are also synthetic 
androgens such as oxandrolone, nandrolone and more importantly synthetic oestrogens (xenoestrogens) such as $17 \alpha$-ethinyl oestrodiol and diethylstilbestrol, used as contraceptives. Some of these compounds are commonly present in wastewater and WTW effluent (Johnson et al., 2000; Standley et al., 2008; Vulliet and Cren-Olivé, 2011).

A related group of compounds are cholesterol and its metabolite $5 \beta$-coprostanol, and the plant sterols stigmastanol, stigmasterol and $\beta$-sitosterol. Plant sterols (phyto-oestrogens) are ingested in edible plants and excreted to wastewater, which may be the largest source of these compounds in the environment (Liu et al., 2010).

\subsection{Ionic liquids}

Ionic liquids are salts with low melting point which are being considered as 'green' replacements for industrial volatile compounds (Thi et al., 2010; Richardson and Ternes, 2011). These compounds include nitrocyclic rings (e.g. pyridinium, pyrrolidinium, morpholinium moieties) and quaternary ammonium salts. Ionic liquids are not yet widely used but current formulations have significant water solubility and are likely to be toxic and poorly degradable (Thi et al., 2010).

\section{Sources, pathways and receptors}

\subsection{Concepts}

Significant risks to human health may result from exposure to non-pathogenic, toxic contaminants that are often globally ubiquitous in waters from which drinking water is derived. The transport of contaminants in the aqueous environment can be described by a source-pathway-receptor model, which considers:

- the source of the contaminant, e.g. sewage sludge spread on to agricultural land

- the pathway by which it travels from the source, e.g. fracture flow through an aquifer

- the receptor, e.g. a consumer drinking tap water

Sources of contaminants to surface waters, groundwater, sediments, and drinking water are varied and include pesticide applications to agricultural land, horticulture, parks, gardens, golf courses, urban infrastructure, and the transport network, discharges or leaks of domestic, hospital or industrial wastewater containing pharmaceutical or personal care compounds, 
sewage sludge application to land, pharmaceuticals and pesticides used to treat animals present in manure stores or applied to agricultural land and solid waste disposal.

Point-source pollution originates from discrete sources whose inputs into aquatic systems can often be defined in a spatially explicit manner. Examples of point-source pollution include industrial effluents (pulp and paper mills, steel plants, food processing plants), municipal WTWs and combined sewage-storm-water overflows, animal waste lagoons, resource extraction (mining), and land disposal sites (landfill sites, industrial impoundments).

Non-point-source pollution, in contrast, originates from poorly defined, diffuse sources that typically occur over broad geographical scales. Examples of non-point-source pollution include agricultural runoff (pesticides, pathogens, and fertilizers), storm-water and urban runoff, and atmospheric deposition (wet and dry deposition of persistent organic pollutants) (Bedding et al., 1982; Ritter et al., 2002). About $70 \%$ of land area in the UK is used for agricultural purposes and about $6 \%$ is urban.

\subsection{Source terms}

Potential source terms include wastewater, derived from domestic, industrial, or hospital premises and waste disposal sites (Bester et al., 2008; Heberer and Feldmann, 2005; Stangroom et al., 1998). The presence of persistent organic pollutants in wastewater, such as polyaromatic hydrocarbons, polychlorinated biphenyls, alkyl phenols, dioxins and furans, chlorinated solvents and benzene derivatives, has been long established (BGS et al., 1998; Rudel et al., 1998, among many others).

The primary sources of pharmaceuticals in the environment are human excretion and disposal of unused products. Hospital waste water forms an important source for a range of EGCs including disinfectants and musks, as well as rare earth elements, heavy metals, and iodised contrast media (Putschew et al., 2000; Sacher et al., 2001; Ternes and Hirsch, 2000; Verlicchi et al., 2010; Watkinson et al., 2009). There are a large number of studies of WTW effluent and septic tanks (Clara et al., 2004; Drewes et al., 2003; Gasser et al., 2010; Glassmeyer et al., 2008; Heberer et al., 1997; Kreuzinger et al., 2004), of raw sewage (Sodré et al., 2009) and of artificial recharge using treated effluent (Cordy et al., 2004; Díaz-Cruz and Barceló, 2008). Manufacturing sites may also contribute (Larsson, 2008; Larsson et al., 2007). There are about 9000 WTWs in the UK serving 95\% of the population (Water UK, 2006). 
The use of veterinary antibiotics in concentrated animal feeding operations is an important source of environmental contamination in the USA and parts of Europe and Asia (BarteltHunt et al., 2010). Veterinary antibiotics have been investigated in various environmental compartments including waste lagoons, groundwater below lagoons, as well as shallow groundwater from areas where animal waste had been applied to fields (Bartelt-Hunt et al., 2010; Hu et al., 2010; Kim et al., 2011; Kolodziej et al., 2004; Sarmah et al., 2006; Watanabe et al., 2010; Watanabe et al., 2008).

Landfill leachates contain large amounts of short and long-chain fatty acids, and can also contain caffeine, nicotine, phenols, sterols, PAH, chlorinated solvents and phthalates (Stuart and Klinck, 1998). The presence of pharmaceuticals in groundwater beneath or downgradient of a landfill has been confirmed by several authors (Ahel and Jelicic, 2001; Ahel et al., 1998; Eckel et al., 1993; Holm et al., 1995). Two recent studies (Barnes et al., 2004; Buszka et al., 2009 ) investigating the occurrence of groundwater down gradient of landfills detected a range of industrial compounds (detergents, antioxidants, fire retardants, plasticisers) as well as PPCPs (antibiotics, anti-inflammatories, barbiturates) and the caffeine and the nicotine metabolite cotinine.

\subsection{Pathways}

For many EGCs the pathway from the source to the receptor is very unclear, since there is a paucity of information for most such novel contaminants. The pathway taken by a contaminant through the environment will depend upon its physicochemical properties, such as its solubility in water.

Direct pathways for pharmaceuticals, urban and industrial contaminants to reach groundwater include leaking sewers, discharge of WWT effluent (directly to ground or to surface water which then infiltrates), landfill leachate, leaking storage tanks and other discharges to the ground that bypass the soil zone, such as septic tanks (Figure 1). Pathways to humans and groundwater from human and animal pharmaceuticals are set out by Boxall et al. (2002), Halling-Sørensen et al. (1998) and Jones et al. (2002). Verma et al. (2007) studied the behaviour of a pharmaceutical in surface and wetland waters.

Contaminants applied to the soil surface will migrate through the soil zone, the unsaturated zone and the saturated zone in the well-established way. This may be the route for agricultural pesticides and components of sewage sludge. The potential for organic 
contaminants present in sewage sludge to leach following application to agricultural land was highlighted by Wilson et al. (1996), although in this study no problems were found using a screening exercise.

Another important pathway is groundwater-surface water interaction. In many instances treated effluent from industrial premises and sewage works is discharged to surface water. This may then infiltrate to groundwater from losing reaches of rivers.

In this review we have not highlighted the atmospheric transmission route as being significant but there may be mechanisms for non-volatile compounds to be mobilised. For example, Hamscher and Hartung (2008) suggest that dust may be a new route for veterinary compounds to enter the environment.

\subsection{Receptors}

Groundwater supplies about one third of public water supply in the UK rising to about $80 \%$ of public supply in the south and southeast of England. It also provides water for industry and irrigation, baseflow support to surface water and aquatic ecosystem health Under the Water Framework Directive (EC, 2000). Receptors, in terms of chemical status, include the groundwater body itself, drinking water abstractions, associated surface waters and directly dependent ecosystems. In parts of south east England, river baseflow from groundwater can be up to $90 \%$ of total flow. Receptors therefore can include human beings drinking tap water, other living creatures such as invertebrates and fish or the environment more widely.

A clear connection between source terms of these contaminants as set out in section 3.2 and groundwater or its receptors is often not well defined enough for significant problems in groundwater to be anticipated. However the risks to such a valuable resource do need to be considered.

\section{Risk assessment for pesticides and their metabolites}

In order to assess the hazards presented by contaminants, information on usage, persistence, leachability and a robust sensitive analytical method is required. For many pesticides these requirements are fulfilled and an assessment of risk of leaching to groundwater can be made. However, the UK metaldehyde problem was not originally discovered due to lack of an analytical method and was exacerbated by recalcitrance to water treatment. For pesticide 
metabolites this information can be sparse, and for other EGCs such as pharmaceuticals it can be lacking.

\subsection{Pesticides}

Pesticides can be synthetic chemical or natural substances and vary in their use, properties and potential impact on the environment. There are currently around 350 ingredients approved for use in agricultural pesticide products in the UK (BCPC and CABI, 2010). Agriculture and horticulture use nearly 80 per cent of all plant protection pesticides in England and Wales. There has been a trend towards more frequent treatments using complex tank mixes but using less persistent compounds and at an overall lower rate of application. Pesticides are also used to control weeds and pests in gardens and weeds on pavements and along railway lines. Pesticides used for seed dressings and biological pesticides were excluded from this study.

Solubility and $\mathrm{K}_{\mathrm{ow}}$ can both give an indication of a compound's mobility and likely sorption in water treatment. $\mathrm{K}_{\mathrm{ow}}$ is commonly expressed as the $\log$ of the coefficient. It is used in environmental fate studies and large values ( +4 or higher) are regarded as an indicator that a substance may tend to bioaccumulate. Conversely, low values indicate environmental mobility. Table 1 shows UK pesticides with the potential to persist in WTW effluent based on their $\mathrm{K}_{\mathrm{ow}}$. They may however, have other properties which are not assessed by this method; bipyridilium compounds such as diquat are cationic and form charge transfer complexes with organic matter (Gevao et al., 2000). Wells (2006) proposes Dow, a pH-dependent coefficient as a better measure of hydrophilicity.

Pesticides most likely to pose a threat include those which remain difficult to analyse at low concentrations and also those in Table 1 which have the potential to persist in drinking water e.g. clopyralid.

\subsection{Pesticide metabolites}

Once released to the environment, pesticides may be degraded by both abiotic and biotic processes. While parent compounds are assessed in detail in many regulatory schemes, the requirements for the assessment of transformation products are less well developed. The potential issue of pesticide metabolites was highlighted by Kolpin et al. (2004) who found atrazine and metalochlor metabolite concentrations present in groundwaters at concentrations higher than the parent compounds. An initial assessment suggested that as many as $30 \%$ of 
pesticide metabolites can be more toxic than the parent compound (Sinclair and Boxall, 2003). Often their different properties can make them difficult to detect and quantify.

Sinclair et al. (2010) reported measured metabolite concentrations in groundwater of the UK. These were all from compounds no longer licensed in the UK: DDT, heptachlor and atrazine. They also reported a desk study of impact on UK surface water derived drinking water based on potential to contaminate water for 53 pesticide metabolites based on parent compound usage, formation rates in soil, persistence and mobility, estimated toxicity and/or potential to exhibit pesticidal activity, the estimated efficiency of removal during drinking water treatment as well as during environmental degradation (Sinclair et al., 2010). This included compounds currently licensed and those which have recently been withdrawn, e.g. atrazine and isoproturon. About half of the compounds had been identified during environmental degradation as well as in mammalian toxicity testing of the parent. For five of the metabolites significant concentrations in surface water derived drinking water were predicted by their model. These were aldicarb sulphone (aldicarb metabolite), 3-carbamyl-1,2,4,5tetrachlorobenzoic acid (chlorothalonil metabolite), cyanazine chloroacid (cyanazine metabolite), desisopropyl atrazine and methomyl (thiodicarb metabolite and also parent compound).

Parsons et al. (2008) carried out an assessment of risk from pesticide metabolites for both the US and the UK. For the UK, 54 pesticides were identified as representing $90 \%$ of all pesticide use. A risk index was used derived from an exposure index, depending on usage, fraction formed, water/organic carbon partition coefficient $\left(\mathrm{K}_{\mathrm{oc}}\right)$ and half life $\left(\mathrm{DT}_{50}\right)$ together with acceptable daily intake. Compounds with the highest risk index were metabolites of cyanazine, followed by those of isoproturon, flufenacet, tebuconazole and dicamba.

Table 2 summarises some European pesticide metabolite studies. Other studies of pesticide metabolites in groundwater, have tended to be in areas where the suite of applications differs from that currently used in the UK (Chang and Liao, 2002; Fava et al., 2005; Giacomazzi and Cochet, 2004; Hancock et al., 2008; Hildebrandt et al., 2007; Kolpin et al., 2004; Montana Dept of Agriculture, 2006).

Worrall et al. (2000) proposed using a probability index for predicting groundwater contamination risk using soil $\mathrm{K}_{\mathrm{oc}}$ and $\mathrm{DT}_{50}$ where points along a diagonal line have a similar estimated leaching probability. A simple assessment for pesticide metabolites for pesticides with UK usage $>50,000$ ha can be made using this method (Figure 2). Estimates of 
persistence, physical properties and leachability data are available from the Footprint website (AERU, 2010) for some metabolites but these are much less comprehensive than for the parent compounds. The line shown is a cut-off between leachers and non-leachers. Values close to the line have been assessed as leachers. Compounds were assessed as non-leachers where $\log \mathrm{K}_{\mathrm{oc}}>4$ and $\log \mathrm{DT}_{50}<0.5$. Key metabolites are shown in Table 3. This approach takes no account of the activity or toxicity of these metabolites and some of the metabolites may be trivial.

The different approaches indicate that the metabolites of chlorothalonil, cyanazine, diflufenican, flufenacet, iodosulfuron-methyl, metaldehyde, metazachlor and metsulfuronmethyl are likely to pose the greatest risk to drinking water. In many cases these metabolites are derived from parent compounds which have a lesser risk.

Glyphosate is now the most widely used herbicide in the world, with dramatic increases in agricultural use since the introduction of glyphosate resistant crops. Microbial degradation produces amino methyl phosphonic acid (AMPA) (Kolpin et al., 2000) and it has been anticipated that AMPA may be problematic. The high water solubility of both the parent and the metabolite has meant that their analysis has been difficult. Kolpin (2006) showed AMPA to be detected in wastewater-impacted surface waters about four times as frequently as the glyphosate parent. Although AMPA has a $\mathrm{DT}_{50}$ of about 151 days and is therefore persistent it also has a relatively high $\mathrm{K}_{\mathrm{oc}}$ of $8087 \mathrm{~mL} / \mathrm{g}$ and would not be classified as vulnerable to leaching by the simple method described above. Similarly for parent compounds which have non-agricultural applications, there will be routes to groundwater which would not be identified, such as routes which bypass the soil zone.

\section{Risk assessment for other emerging contaminants}

These include pharmaceuticals, personal care products, lifestyle compounds, and industrial compounds. Many of this group of compounds cannot as yet be assessed in the same way due to a lack of persistence data since the majority of studies have been directed at water treatment. There is a scarcity of data on human health effects at environmental levels, effects on aquatic organisms, and other harmful effects and therefore it is difficult to predict which health effects they may have on humans, terrestrial and aquatic organisms, and ecosystems. Studies often use a mixture of physical properties, degradation rates and monitoring case studies to reach an assessment. Many of these compounds are considered to be persistent in 
the aqueous environment. However, it is characteristic of some contaminants that they do not need to be persistent to cause negative effects since their high transformation/removal rates is compensated by their continuous introduction into the environment (EUGRIS, 2011).

\subsection{Attenuation in treatment works}

The effective operation of WTWs plays an important role in minimising the release of xenobiotic compounds into the aquatic environment (Byrns, 2001). A feature of some emerging contaminants is their recalcitrance to sewage treatment (Heberer, 2002b) or drinking water treatment which allows them to pass through into the treated water (Zwiener, 2007).

\subsubsection{Wastewater treatment}

The first concerns regarding the potential adverse effects of pharmaceuticals in wastewater were expressed in the 1960s following a study of oestrogenic hormones in activated sludge (Stumm-Zollinger and Fair, 1965). A review of implications for the US water industry is provided by Snyder et al. (2003) starting from an analytical perspective.

Joss et al. (2006) showed that efficiency of elimination of micro-organics depends on the relative rate of degradation and retention times in the plant. Maurer et al. (2007) showed that $\beta$-blockers were incompletely removed in WTW due to both to limited sorption and degradation rates similar to the retention time. Many pharmaceuticals which pass through treatment may not be in the fully dissolved state and are often as glucuronaric acid or sulphate conjugates which enhances their polarity before excretion, and makes them harder to remove, but which can be cleaved during treatment to release further active ingredient (Ternes et al., 2004).

Rosal et al. (2010) report a survey of over 70 individual pollutants in a WTW effluent using biological treatment followed by ozonation where several important groups of pharmaceuticals had typical removal efficiencies of $<20 \%$. Ashton et al. (2004) suggested that most WTWs in England and Wales are likely to be routinely discharging small quantities (ng/L) of pharmaceuticals. A number of other studies have similar findings (Carballa et al., 2004). A study in Sweden found diclofenac at higher concentrations in the effluent than in the influent (Zorita et al., 2009). 
The oestrogenic effects of WTW effluent ascribed to ethinyl oestradiol and alkyl phenols have been recognised for two decades (Montagnani et al., 1996; Purdom et al., 1994). Rutishauser et al. (2004) showed that in-vitro tests were able to detect oestrogenic effects in effluents from these compounds and bisphenol A. An assessment of oestrogen removal efficiency for WTW in the UK (Johnson et al., 2007b) showed simple biological plants to be poor with only about $30 \%$ removal. Johnson and Williams (2004) were able to estimate the amount likely to be discharged using predictions of excretion fate and behaviour in the wastewater treatment system.

Degradation of APEs in WTWs generates more persistent shorter-chain APEs and alkyl phenols such as NP, OP and alkylphenol mono- to tri-ethoxylates (Ying et al., 2002). The physicochemical properties of APE metabolites indicate that they will have a significant load in sediments and sludges. APE removal can be enhanced by GAC filtration, UV treatment or ozonolysis but these techniques do not resolve accumulation in sludge (Soares et al., 2008).

Horii et al. (2007) showed that removal efficiencies for synthetic musks by WTWs ranged from $72 \%$ to $98 \%$ but concentrations of the galaxolide metabolite HHCB-lactone increased during treatment. Flame retardants may be present in effluent from WTWs accepting landfill leachate (Rahman et al., 2001). This may also be a route for other industrial compounds.

Byrns (2001) showed that the effect of some operating parameters has an important influence upon the concentration of xenobiotics released in the sludges and final effluent. This may have significance for a wide range of ecotoxic compounds and in particular the class of compounds increasingly recognised as having the potential to disrupt endocrine activity in some aquatic invertebrates.

\subsubsection{Drinking water treatment}

For drinking water the main types of treatment processes relevant to micro-organics are: clarification/coagulation, granulated or powdered activated carbon (GAC or PAC) sorption, oxidation using ozone or chlorine and membrane filtration. In order to assess removal it is critical to understand their size distribution and particulate and colloidal association of micro contaminants in raw drinking water (Snyder et al., 2003).

Filtration using GAC has been widely used to remove organic micropollutants from drinking water and is effective in removing emerging contaminants provided that it is correctly managed. Removal may be up to $90 \%$ for refractory compounds (Schäfer et al., 2002). Its 
effectiveness is greatly reduced by the presence of natural organic matter which competes for binding sites, or particulates which block the pore spaces (Bolong et al., 2009; Snyder et al., 2007). PAC is more efficient since it is fed as a new product and is not recycled through the treatment process whereas GAC can have a greater absorption capacity, particularly if steam treated, but needs regular replacement (Snyder et al., 2007). However, small and/or very polar molecules can be difficult to remove by this method.

Membrane filtration, either by nanofiltration or reverse osmosis, has considerable potential to remove a wide range of emerging contaminants (Nghiem et al., 2005a; Nghiem et al., 2005b; Snyder et al., 2007). Membrane filtration can provide good removal except for lower molecular weight uncharged compounds (Snyder et al., 2007). Verliefde et al. (2007) assessed the application of nanofiltration to priority pollutant removal from water sources. Nanofiltration was particularly effective for negatively charged compounds (Zwiener, 2007). Membrane cleaning requires careful management (Nghiem and Schäfer, 2006).

Chlorine and chlorine dioxide have been shown to be ineffective and also produced undesirable by-products (Zwiener, 2007). Chlorine dioxide is anticipated to react particularly with compounds containing phenolic amino and thio functions (Snyder et al., 2003). In a study of 98 organic micro-compounds, Gibs et al. (2007) showed that 50\% were not substantially degraded by combined and free chlorine.

Reactions with ozone are reviewed by Snyder et al. (2003). Advanced oxidation, which uses a combination of ozone with other oxidation agents such as UV radiation, hydrogen peroxide or $\mathrm{TiO} 2$, generates reactive intermediates and includes electrochemical mineralisation and solar photocatalysis (Comninellis et al., 2008). This is limited by the radical scavenging capacity of the matrix and can be expensive (Petrović et al., 2003).

Ternes et al. (2002) investigated the elimination of selected pharmaceuticals (bezafibrate, clofibric acid, carbamazepine, diclofenac) during drinking water treatment processes at laboratory and pilot scale and in real waterworks. No significant removal of pharmaceuticals was observed in batch experiments with sand filtration under natural aerobic and anoxic conditions, thus indicating low sorption properties and high persistence with non-adapted microorganisms. Flocculation using iron(III) chloride in lab-scale experiments and investigations in waterworks exhibited no significant elimination. However, ozonation was in some cases very effective in eliminating the polar compounds diclofenac and carbamazepine 
and reducing bezafibrate. Except for clofibric acid, GAC in pilot-scale experiments and waterworks provided a major elimination of the pharmaceuticals under investigation.

Westerhoff et al. (2005) reviewed the effectiveness of a range of drinking water treatment processes for emerging contaminants on the laboratory scale. Aluminium sulphate and ferric chloride coagulants or chemical lime softening removed $<25 \%$ of most emerging contaminants (ECs). PAC effectiveness was variable, from 10 to $90 \%$ depending on compound polarity $\left(\mathrm{K}_{\mathrm{ow}}\right)$. Ozone oxidized steroids containing phenolic moieties (oestradiol, ethinyloestradiol, or oestrone) more efficiently than those without aromatic or phenolic moieties (androstenedione, progesterone, and testosterone). EC reactivity with oxidants were separated into three general groups: (1) compounds easily oxidized ( $>80 \%$ reacted) by chlorine are always oxidized at least as efficiently by ozone; (2) 6 of the 60 compounds (TCEP, BHC, chlordane, dieldrin, heptachlor epoxide, musk ketone) were poorly oxidized $(<20 \%$ reacted) by chlorine or ozone; (3) compounds (24 of 60) reacting preferentially (higher removals) with ozone rather than chlorine.

In an overall assessment for 113 organic micro-compounds Stackelburg et al. (2007), 15\% of the loading was removed by clarification, $32 \%$ by hypochlorite disinfection and $53 \%$ by GAC filtration. Compounds most frequently detected in finished water were carbamazepine, DEET, cotinine, tonalide, caffeine and camphor.

The efficacy of drinking water treatment for pharmaceuticals was evaluated for GAC, oxidation and membrane filtration by Zweiner (2007). A good correlation was found between the percentage removal by activated carbon and the octanol/water partition coefficient $\left(\mathrm{K}_{\mathrm{ow}}\right)$ for many compounds with $\log \mathrm{K}_{\mathrm{ow}}>3$. High rates of removal by ozonation are usually observed for compounds with double bonds, aromatic structure or heteroatoms, and this was the case for diclofenac, carbamazepine and sulfamethoxazole (Zwiener, 2007). Lower rates were observed for clofibric acid and ibuprofen which do not have reactive sites. These types of compounds are more readily degraded by advanced oxidation using, for example, the $\mathrm{OH}$ radical.

Escher et al. (2009) assessed the efficiency of removal of toxicological activity by ozonation after secondary treatment using bioassays and compared that with removal using GAC. Escher et al. (2006) estimated the removal efficiency of pharmaceuticals and hormones in separated urine using both bioassays and chemical analysis. This approach was extended to 
the ecotoxicological effects of polar micro-organics in effluent and receiving surface waters (Escher et al., 2008).

In conclusion we can assume that there is potential for some EGCs to pass through drinking water treatment plants. Many such plants which treat groundwater may not have treatment which would remove these types of compounds as groundwater has a lower organic loading than surface water.

\subsection{Attenuation in the environment}

Physicochemical properties such as $\mathrm{K}_{\mathrm{ow}}$ are available for many of urban and industrial organic micropollutants from the SRC database (SRC, 2010). As a first pass estimate of recalcitrance to water treatment, of the compounds listed by Gibs et al. (2007), Stackelberg et al. (2007) and Glassmeyer et al. (2008), only 19 had a $\mathrm{K}_{\mathrm{ow}}$ of $<1$.

Zweiner (2007) describes the processes which reduce the concentrations of pharmaceuticals in treated sewage effluent in the aqueous environment as biodegradation, sorption, photolysis and oxidation successively in surface water, bank filtration and drinking water treatment. Most degradation studies have been directed at degradation in surface water (Pal et al., 2010). Pal et al. (2010) also collated physicochemical properties reported in the literature for 14 pharmaceuticals demonstrating their wide range. In general amines have higher sorption coefficients than carboxylic acids and neutral pharmaceuticals (Yamamoto et al., 2009). Lai et al. (2000) showed that synthetic oestrogens were more readily removed from the aqueous phase in rivers and estuaries than natural compounds due to their higher $\mathrm{K}_{\mathrm{ow}}$. Sorption was to both organic carbon and iron oxides in sediments.

Oppel et al. (2004) studied the leaching behaviour of 6 selected pharmaceuticals in different soils to simulate soil application. The results indicated that the leaching potential was low for diazepam, ibuprofen, ivermectin and carbamazepine, but clofibric acid and iopromide were very mobile under the experimental conditions.

Drewes et al. (2003) showed that caffeine, gemfibrozil and many analgesics were removed from recharged treated effluent during groundwater recharge within six months, whereas carbamazepine and primidone persisted for up to 8 years. For a group of 8 pharmaceuticals Lam et al. (2004) showed that photolysis was much more significant than hydrolysis. Jürgens et al. (2002) measured the degradation of oestrodiol and ethinyl oestrodiol in English rivers and estimated a half-life of 10 days or less. Synthetic musks are assessed as being non- 
degradable with sorption and sedimentation being minor processes. Tonalide can be removed from surface water by direct photolysis but galaxolide shows negligible photochemical degradation (Buerge et al., 2003).

Jones et al. (2002) made an environmental assessment for the 25 most-used prescription pharmaceuticals in the UK based on usage, removal in treatment works based on sorption and dilution. Degradation was modelled due to lack of data and was predicted to be very limited for most compounds. Jones et al. (2005) assessed the potential for pharmaceuticals to enter the aqueous environment, reviewed the levels reported in drinking water world-wide and assessed the implications.

Lindström et al. (2002) detected triclosan and its metabolite methyl triclosan in surface water in Switzerland and considered the metabolite to be persistent.

Löffler et al. (2005) studied four 14C-labelled pharmaceuticals (diazepam, ibuprofen, iopromide, and acetaminophen) as well as six non-labelled compounds (carbamazepine, clofibric acid, 10,11-dihydroxycarbamazepine, 2-hydroxyibuprofen, ivermectin, and oxazepam) in batch studies of water/sediment. Ibuprofen, 2-hydroxyibuprofen, and paracetamol displayed a low persistence with $\mathrm{DT}_{50}$ values in the water/sediment system less $<20 \mathrm{~d}$ and paracetamol was rapidly attenuated due to the extensive formation of bound residues. A moderate persistence was found for ivermectin, iopromide and oxazepam with $\mathrm{DT}_{50}$ values of $<60 \mathrm{~d}$. For diazepam, carbamazepine, 10,11-dihydroxycarbamazepine, and clofibric acid, system DT $_{90}$ values of $>365$ days were found. An elevated level of sorption onto the sediment was observed for ivermectin, diazepam, oxazepam, and carbamazepine.

Johnson et al. (2007a) applied an existing GIS model to predict the concentrations of the pharmaceuticals, diclofenac and propanalol, in surface water catchments. The model input parameters included consumption, excretion and fate. Concentrations predicted throughout the catchments were $1 \mathrm{ng} / \mathrm{L}$ under low flow except for downstream of small WTW where concentrations of up to $25 \mathrm{ng} / \mathrm{L}$ were predicted.

Kavlock et al. (2008) reviews the types of model which can be used to estimate physicochemical properties and degradation mechanisms in the environment, and examples are shown in Table 4.

The fate and transport of emerging contaminants in the aqueous environment remains poorly understood, particularly for groundwater. Established contaminants, such as pesticides, often 
have persistence in groundwater of up to an order of magnitude longer than in soils and surface water.

\subsection{Toxicity}

\subsubsection{Lifestyle and personal care products}

Pathways to humans will also include direct exposure through ingestion, inhalation or dermal contact and the risk posed by drinking water is likely to be considerably less.

Caffeine and nicotine have been included in a number of studies of pharmaceutical fate (e.g. Debska et al., 2004; Santos et al., 2007; Schwab et al., 2005). Caffeine's effect on the environment is not well understood, but does not appear to give cause for concern to freshwater organisms at currently detected concentrations (Moore et al., 2008). Nicotine has a high toxicity to humans, compared to other alkaloids and neonicotinoid pesticides, such as imidacloprid, are widely used. The toxicity of artificial sweeteners as food additives is reviewed by Grice and Goldsmith (2000) and by Whitehouse et al. (2008).

DEET has been found to inhibit the activity of a central nervous system enzyme, acetylcholinesterase, in both insects and mammals (Corbel et al., 2009). Collated information on DEET in the aquatic environment suggested risk to aquatic biota at observed environmental concentrations is minimal.

The parabens exert a weak oestrogenic activity (Oishi, 2002; Soni et al., 2002) and are capable of producing immunologically mediated, immediate systemic hypersensitivity reactions (Nagel et al., 1977). Some data on their environmental toxicity is now available (Bazin et al., 2010). Fatta-Kassinos et al. (2010) considered that n-butyl and benzyl parabens should be classified as toxic substances whereas methyl, ethyl and n-propyl parabens are harmful. A synergistic oestrogenic effect was observed when other estrogenic compounds were also present.

Triclosan is degraded to dioxins and is toxic to aquatic bacteria at levels found in the environment (Ricart et al., 2010).

Work on toxicity of musks has mainly assumed a dermal exposure pathway (Ford et al., 2000). They are degraded to more polar metabolites during treatment and in sediments and the soil. Heberer (2002a) discusses the results from investigations of synthetic musk concentrations found in sewage, sewage sludge, surface water, aquatic sediment, and biota 
samples in terms of bioaccumulation, metabolism in fish, and environmental and human risk assessment.

Many "lifestyle" and PCPs which are commonly used may exhibit some toxic effects on humans or the environment.

\subsubsection{Industrial compounds}

The toxicological effects of many industrial compounds are long established; information is also available for many emerging compounds.

Polybrominated diphenyl ether (PBDE) flame retardants have been found to bioaccumulate and have potential endocrine disrupting properties (Hooper and McDonald, 2000; Meerts et al., 2001; Rahman et al., 2001). Tris-(2-chloroethyl) phosphate (TRCP), which is used in industrial and consumer products, appears to be responsible for brain damage (Matthews et al., 1993). There is relatively little information on PFOS toxicity (Hekster et al., 2003).

Octyl and nonyl phenol have been long established as endocrine disruptors in fish (Petrović et al., 2004; White et al., 1994). The APEs can also be used as pesticide adjuvants. These can therefore be found in groundwater as a result of agricultural activity (Lacorte et al., 2002; Latorre et al., 2003). Thomas et al. (2001) used the toxicological impact of a storm event in an agricultural catchment near Tunbridge Wells to determine that significant components not being measured were present, and used this to identify the surfactant nonylphenol as well as the pesticides diuron, simazine endosulphan sulphate and pendimethalin.

Both the water treatment by products NDMA and acrylamide affect the central nervous system and are carcinogenic (Smith and Oehme, 1991).

Eljarrat and Barceló (2003) attempted to prioritize emerging and persistent organic pollutants in the environment based on their relative toxic potency. These included dioxins and polybrominated compounds.

Carlsson et al. (2006) assessed 27 active ingredients, with 9 being identified as dangerous for the aquatic environment and only oestradiol and ethinyloestradiol considered to have possible aquatic environmental risks.

Farré et al. (2008) review the fate and the ecotoxicology of emerging pollutants, especially focusing on their metabolites and transformation products (TPs) in the aquatic environment, 
including pharmaceuticals, hormones, perfluorinated compounds, by-products of drinkingwater disinfection, sunscreens or UV filters, benzotriazoles and naphthalenic acids.

Poynton and Vulpe (2009) applied an ecotoxicogenomic approach to assess the potential effects of a range of pharmaceuticals, endocrine disruptors, polybrominated flame retardants, perfluorinated compounds and nanomaterials. DNA-microarrays can be used to understand the effects of single compounds and mixtures, to suggest potential modes of action and predict exposure to pollutants in the environment.

Schriks et al. (2010) derived provisional drinking water values for a selection of emerging contaminants based on toxicological literature data. Where no published values existed these were derived from the ADI or failing this from the LOEC/NOEC. These were compared with occurrence data for surface water of the Rhine and Meuse. This study identified 1,4-dioxane, benzene and NDMA as being found at the highest concentrations relative to the guidelines. PFOS and PFOA were also highlighted. For groundwater the highest concentrations were for the fuel-oxygenate methyl tertiary-butyl ether.

\subsection{Synergistic toxic effects}

Concern over the potential adverse health effects of groundwater contaminated by a cocktail of contaminants has existed for many years (Germolec et al., 1989). The implications for mixtures of herbicides considered by WHO, who stated in 1987 that not these could not be handled in isolation (WHO, 1987). Carpy et al. (2000) reviewed the possible effects of pesticide mixtures and Relyea (2009) showed how aquatic communities can be dramatically impacted by a cocktail of low concentrations of pesticides. Yang et al. (1989) describe the approaches to evaluating the toxicology of chemical mixtures. Seed et al. (1995) discuss the applicability and validity of the methods for the assessment of risk posed by exposure to environmentally relevant concentrations of chemical mixtures. Borgert et al. (2001) describe a set of criteria to: evaluate the quality of data and interpretations in chemical interaction studies said to reflect the consensus of the literature on interaction analysis which apply to interaction data for drugs, pesticides, industrial chemicals, food additives, and natural products.

In a different approach Eljarrat and Barceló (2003) define a toxic equivalency factor (TEF) which provides a single number that is indicative of the overall toxicity in a mixture of related compounds. They used this for a mixture of dioxin and dioxin analogues. 
Pomati et al. $(2006 ; 2008)$ investigated the effects and interactions of a mixture of commonly used pharmaceuticals, including carbamazepine, ibuprofen and sulfamethoxazole at low concentrations, designed to mimic those found in the environment using in vitro tests on human and zebrafish cells. They concluded that a mixture of drugs at ng/L levels can inhibit cell proliferation by affecting their physiology and morphology and that waterborne pharmaceuticals may have an effect on aquatic life.

Synergy remains an important topic with the complex mixtures of trace organic compounds being released to the environment.

\subsection{Risk assessment}

In their editorial to the special issue of Water Research 'Emerging contaminants in water' Ternes and von Gunten (2010) state that to elucidate the relevance of micropollutants in aquatic systems their (eco)toxicological potential must be addressed. Almost all studies of risk to the aquatic environment have been directed to surface water; risk assessment to humans from consumption of surface water has therefore been used as an analogue for groundwater accepting that groundwater itself may be less at risk from emerging contaminants.

In an early review, Halling-Sørensen et al. (1998) collated concentrations of pharmaceuticals in the environment from human and veterinary use and also assessed their environmental fate and toxicity. They concluded that pharmaceuticals were present in the environment at concentrations similar to other xenobiotics, and highlighted the paucity of information.

The principles of human risk assessment are set out by Lioy (1990) and these are illustrated using a flow diagram relating the source of contaminant to health effects in humans. Risk assessments of pharmaceuticals in the aquatic environment use the comparison of predicted environmental concentration (PEC) and predicted no-effect concentration (PNEC) derived from the Acceptable Daily Intake (ADI). The process for registration of new drugs at the European level requires a risk assessment of the PEC using data on the volume of drug prescribed and the amount of dilution in the wastewater stream (EMEA, 2005). The method assumes "no biodegradation or retention of the drug substance in the WTW". This approach can also be used to assess existing compounds. Bound and Voulvoulis (2006) used the proportion of the population being treated, the dosage, the amount of wastewater generated 
per day and an estimate of dilution to identify candidate compounds for a study of pharmaceuticals in UK rivers.

Stuer-Lauridsen et al. (2000) calculated the PEC using the amount of compound used divided into the amount of wastewater generated both per capita diluted into the environment using a default value of 10 , and estimating $\mathrm{K}_{\mathrm{ow}}$ and $\mathrm{DT}_{50}$ from literature values. They found limited ecotoxicity data to be available for calculation of PNEC and showed for the six compounds possible, PEC/PNEC $>1$ for ibuprofen, paracetamol and acetyl-salicylic acid. Webb (2000) made a similar assessment for drugs used in the UK in 1995. Of the 67 compounds assessed only 7 had PEC/PNEC $>1$ and only 11 had PEC/PNEC $>0.1$.

Schwab et al. (2005) and Cunningham et al. (2009) presented human health risk assessments for a range of active pharmaceutical ingredients and/or their metabolites, representing different drug classes, using environmental monitoring data. ADIs were used to estimate PNECs for both drinking water and fish ingestion. The PNECs were compared to measured environmental concentrations (MECs) from the published literature and to maximum PECs generated using the regional assessment models PhATE $^{\mathrm{TM}}$ (Anderson et al., 2004) for North America and GREAT-ER (Feijtel et al., 1997) for Europe. The model predictions assumed low river flow and no depletion (no metabolism, no removal during wastewater or drinking water treatment, and no instream depletion). Ratios of MECs to PNECs were typically very low and consistent with PEC to PNEC ratios. For all 26 compounds, these low ratios indicate that no appreciable human health risk exists from the presence of trace concentrations in surface water and drinking water.

Straub (2008) reviewed the derivation of PECs, PNECs and MECs for diazepam by both deterministic and probabilistic procedures and the probabilistic safety margin. No significant concern was identified. In contrast, Cooper et al. (2008) ranked drugs by their potential environmental exposure and risk using annual prescriptions dispensed, surface water concentrations, effluent concentration, environmental half life, biological half life, mammal, fish and crustacean toxicity, $\mathrm{K}_{\mathrm{ow}}$, solubility and ECOSAR (model used to estimate the aquatic toxicity of industrial chemicals). These were compiled into the PEIAR (Pharmaceuticals in the Environment, Information for Assessing Risk) database (CHBR, 2009). A preliminary assessment indicated that anti-infective, cardiovascular and central nervous system (analgesic, anti-inflammatory and psychotherapeutic) pharmaceuticals had the highest risks. 
Toxicological and ecological assessments for pharmaceuticals are summarised by Pal et al. (2010). These used toxicity tests using freshwater invertebrates, fish, mussels and human embryonic cells. The sex hormones were viewed to be of the greatest concern, followed by cardiovascular drugs, antibiotics and anthineoplastics (chemotherapy drugs) (Sanderson et al., 2004a). Currently, antibacterial resistance represents the most significant human health hazard, and potentially the largest non-target organism hazard is sex hormones acting as endocrine modulators in wildlife.

In a study which did include groundwater, Schulman et al. (2002) assessed the risk to human health for 4 representative pharmaceuticals: acetylsalicylic acid, clofibrate, cyclophosphamide, and indomethacin which have been detected in aqueous environmental media including WTW effluent, surface water, drinking water, and groundwater. The toxicological and pharmacological nature, exposure assessment, and environmental fate and transport of each pharmaceutical were considered. The overall conclusion was that based on available data there was appreciable risk to humans, as the detected concentrations of each compounds were far below the derived safe limits.

A number of studies have assessed the risk to aquatic organisms using species dependent criteria. Ferrari et al. (2003) calculated PNEC from bioassays for bacteria, algae, microcrustaceans, and fishes to perform an initial risk characterization against both MEC and PEC for carbamazepine, clofibric acid, and diclofenac. Only carbamazepine had a risk quotient $>1$. Sanderson et al. (2004b) ranked 2986 different pharmaceutical compounds in 51 classes relative to hazard toward algae, daphnids, and fish using a quantitative structureactivity relationship (QSAR) type model. Modifying additives were the most toxic classes. Cardiovascular, gastrointestinal, antiviral, anxiolytic sedatives hypnotics and antipsychotics, corticosteroid, and thyroid pharmaceuticals were the predicted most hazardous therapeutic classes.

A review by Fent et al. (2006) found that only very little is known about long-term effects of pharmaceuticals to aquatic organisms, in particular with respect to biological targets. For investigated pharmaceuticals the chronic lowest observed effect concentrations (LOEC) in standard laboratory organisms are about two orders of magnitude higher than maximum concentrations in WTW effluents. For diclofenac, the LOEC for fish toxicity was in the range of wastewater concentrations, whereas the LOEC of propanolol and fluoxetine for zooplankton and benthic organisms were near to maximal effluent concentrations. 
Kostich and Lazorchak (2008) used a simple approach, prioritising pharmaceuticals using marketing data and predicted concentrations of likely activity in wastewater to evaluate the risk to aquatic organisms using PECs. This approach was extended by comparison with regulatory data (Kostich et al., 2010).

A preliminary risk assessment for a range of PCPs in surface water made by Brausch and Rand (2010), using both environmental fate data and toxicity to aquatic organisms, suggested that only triclosan and triclocarban presented any hazard but this did not take account of endocrine effects.

Overall it is concluded that the sex hormones, PFOS and PFOA, diclofenac, carbamazepine and ibuprofen present the greatest risks to surface water, with possibly benzene and 1,4dioxane. However the risk assessment approaches available may not be adequate for the groundwater environment where inputs may not be the same and where environmental conditions controlling fate and transport may be very different from the surface.

\section{UK and European studies}

\subsection{Surface water}

A possible indication of future groundwater contamination may be given by current surface water issues. It has long been recognised that the pollutant loading to surface waters is both temporally and spatially variable (Haith, 1985; Vega et al., 1998) although the risk and uncertainty can be modelled (Persson and Destouni, 2009).

A summary of published work related to detection of organic micropollutants in UK surface waters is shown in Table 5. This demonstrates that a wide range of pharmaceuticals as well as industrial compounds and pesticides that have been detected. Most of these studies have been associated with the impact of WTWs. It is well established that endocrine disruption in UK rivers is likely and due primarily to natural and synthetic oestrogens in sewage effluents (Johnson et al., 2007b). Mason et al. (1999) showed that point source contamination of surface water from pesticides was more significant than previously recognised.

Loos et al. (2009) report an EU-wide reconnaissance of the occurrence of polar organic persistent pollutants in European river waters. Samples from over 100 rivers from 27 European countries were analysed for 35 compounds, comprising pharmaceuticals, pesticides, PFOS, PFOA, benzotriazoles, hormones and endocrine disrupters. The compounds 
detected most frequently and at the highest concentrations were benzotriazole, caffeine, carbamazepine, tolyltriazole and nonyl-phenoxy acetic acid. Only about 10\% of the river water samples analysed could be classified as "very clean" in terms of chemical pollution.

\subsection{Groundwater}

Table 6 summarises European studies of organic micropollutants in groundwater. These confirm the detection of emerging contaminants such as ibuprofen, carbamazepine, diclofenac and sulfamethoxazole.

Loos et al. (2010) report a pan-European reconnaissance for polar persistent organic pollutants in groundwater. In total, 164 individual groundwater samples from 23 European countries were collected and analysed (among others) for 59 selected organic compounds, comprising pharmaceuticals, antibiotics, pesticides (and their metabolites), perfluorinated acids (PFAs), benzotriazoles, hormones, alkylphenolics (endocrine disrupters), caffeine, DEET, and triclosan.

Figure 3 shows the frequency of detection for compounds present in $20 \%$ or more of samples and the maximum concentrations detected by Loos et al. (2010). The most relevant compounds in terms of both frequency of detection and maximum concentrations detected were DEET, caffeine, PFOA, atrazine, desethylatrazine, 1H-benzotriazole methylbenzotriazole, desethylterbuthylazine, PFOS, simazine, carbamazepine, nonylphenoxy acetic acid, bisphenol A, perfluorohexane sulfonate terbuthylazine, bentazone, propazine, perfluoroheptanoic acid, 2,4-dinitrophenol, diuron and sulfamethoxazole.

In an investigation into the occurrence of perfluorinated compounds in groundwaters of England and Wales in 2006, perfluorinated compounds were detected in 26\% (57 of 219) of groundwater monitoring sites, with detectable concentrations of PFOS found at about $14 \%$ of sites (Environment Agency, 2007; Environment Agency, 2008).

Data from the Environment Agency's monitoring programme for organic pollutants presented in this study indicates that within the 30 most frequently detected compounds are a number of emerging contaminants: atrazine metabolites, caffeine and DEET (Figure 4). Specific determinands with multiple detections include pesticides metabolites, pharmaceuticals including carbamazepine, triclosan, nicotine, food additives and alkyl phosphates (Table 7).

This data set is not directly comparable with Loos (2010) since it contains non-polar compounds, fewer pesticides and perfluorinated compounds, has a different limit of detection 
and is designed to capture compounds which do not form part of standard monitoring suites. Figure 5 shows the percentage detection for top 15 compounds from this study excluding hydrocarbons, PAH and chlorinated solvents compared with that reported for the same compounds by Loos et al. (2010).

\subsection{Comparison of river and groundwater concentrations}

These studies allow us to make a comparison between surface and groundwater. Concentrations of some contaminants are much higher in surface than groundwater as might be anticipated. For example, average concentrations of ibuprofen 100 times higher in rivers than groundwater, caffeine 75 times and carbamazepine 21 times. PFOA, ketoprofen, sulfamethoxazole and oestrone are also relatively elevated in river water.

However desethyl atrazine, bisphenol A, 4-octyl phenol are higher in groundwater. Clearly this could be related either to a different source and pathway of entry, but it could of course also be related to their different degradation rate in the subsurface.

These data allow us to begin to identify important sources and routes to groundwater in the UK. The widespread detection of atrazine and its metabolites, and the recent problems with metaldehyde, show that diffuse sources such as agricultural and amenity pesticide use remain important. Pharmaceuticals, personal care products and lifestyle compounds are most likely to be derived from WTWs discharge either to the ground, or from sewer leakage, or through surface water/groundwater interaction. It is possible that some older compounds are the results of leakage from landfills which have received domestic or medical waste. PFOS and PFOA may have been released as the results of incidents such as fires and may both have infiltrated directly to groundwater or via surface water. We might conclude that all of the above routes need to be taken into account.

It is clear that the risks to groundwater and its receptors are real. Loos et al. (2010) report seemingly high concentrations of some compounds, but we as yet have insufficient data to be able to evaluate the significance of these findings. Many groundwater sources do not have treatment which would remove emerging contaminants and their lack of drinking water limits means that they are not currently being monitored. Much more research is needed to demonstrate whether emerging contaminants in river baseflow or groundwater dependent ecosystems are or could potentially have an impact. 


\section{Challenges in the management of emerging contaminants}

\subsection{Identifying emerging contaminants}

The first challenge will be to identify the chemicals which potentially will become dangerous in the future and minimise the potential threat to groundwater, and to its receptors. To evaluate this threat the scientific community will need to:

- identify possible new groundwater pollutants

- identify possible new sources of such pollutants,

- develop analytical methods to measure these compounds in a variety of matrices (e.g. water, sediment, waste) down to trace levels.

- determine the environmental occurrence of these potential contaminants,

- characterize the sources and source pathways that determine contaminant release to the aqueous environment,

- identify possible new pathways for human exposure from contaminated groundwater, such as vapour intrusion.

- define and quantify processes that determine their transport and fate through the environment, and

- identify potential ecologic effects from exposure to these chemicals or microorganisms

Daughton (2004) raises a number of issues relating to the management of emerging contaminant problems.

- growing questions about pervasiveness and significance of low level effects, and awareness that there may be effects from concentrations below the toxic limit

- issues that may occur from inadequate water infrastructure and decentralised water use

- consequences of water reuse and artificial groundwater recharge

- pollution prevention, early warning programmes, monitoring programmes, use of pollutants as indicators,

- changing consumer behaviour and risk perception, communicating risk, new precautionary principles.

These represent major challenges for both the science community and those with responsibilities for risk assessment and managing pollution. 


\subsection{Setting appropriate standards}

The Water Framework Directive (EC, 2000) and its Groundwater Daughter Directive (EC, 2006) require the setting of threshold values (TVs) for groundwater as part of the assessment of groundwater bodies. TVs have to be set for all pollutants which put the groundwater body at risk of failing to achieve good status. In setting TVs the following criteria must be considered:

- extent of interaction of groundwater and ecosystems,

- toxicology, dispersion tendency, persistence and bioaccumulation potential.

For EGCs the establishment of TVs, if necessary, will be a challenging task and require much better understanding of key properties and their distribution and behaviour in groundwater. As such for individual compounds, this likely to be a lengthy process.

Khadam and Kaluarachchi (2003) set out a multi-criteria decision analysis framework for environmental decision making in subsurface contamination remediation scenarios using probabilistic health risk assessment and economic analysis, in their case for carcinogenic impacts.

The methodology uses the trade-off between:

- $\quad$ population risk and individual risk by establishing a risk index

- the residual risk and the cost of risk reduction by using cost per life saved as a criterion

- cost-effectiveness as a justification for remediation.

Three approaches to ranking the criteria for decision-making were explored: structured explicit decision analysis, a heuristic approach and fuzzy logic. The results showed the importance of using an integrated approach for decision-making considering both costs and risks.

A similar approach could be developed for establishing what levels of discharge controls and drinking water treatment would be appropriate to achieve an acceptable water quality at a realistic cost. An adaptation of the flowchart developed by Khadam and Kaluarachchi (2003) is shown in Figure 6. The pathway here could either be entry to the environment or migration in groundwater. 


\subsection{Reducing inputs}

There are a number of different areas which need to be tackled to reduce the overall input of emerging contaminants to groundwater. These include better handling and use, minimising waste product, correct disposal, reducing discharge to surface or groundwater and improved drinking water treatment.

For example Kümmerer (2008) and Eckstein and Sherk (2011) set out a number of strategies for reducing PPCP and veterinary medicines in water resources through better control of the source term and minimising wastes, in addition to improved monitoring and regulating compounds entering water. These include:

- $\quad$ product design - maintenance of effectiveness despite reduced dosage

- delivery - more precise targeting and dosing, better delivery routes (e.g. transdermal), completion of course to reduce disposal

- marketing - guidance on disposal, broader range of package size, advertising

- publication of environmental risk assessment data

- dispensing - expiry date, pharmacy inventories, database of both prescription and non-prescription drugs, reduction in availability of non-prescription drugs

- restrictive prescription, and improvement in hygiene for farm animals

- disposal/recycling - effective guidance, reverse distribution (take back programmes), recovery from wastewater

- reduction of input by broken sewage/piping

- separation of waste and rainwater to minimise necessary treatment

- alternative products - improved nutrition, probiotic products

- demonstration of economic benefits of usage reduction by health insurers

A major challenge in wastewater and drinking treatment is to improve existing processes and to design new ones to remove a large number of very different micropollutants in a range of matrices (Schwarzenbach et al., 2006). Future water treatments will require the development of more compact and efficient technologies. Existing strategies that predict relative removals of herbicides, pesticides, and other organic pollutants by activated carbon or oxidation can be directly applied for the removal of many ECs, but these strategies need to be modified to account for recalcitrant species (Westerhoff et al., 2005). Advanced oxidation and solar photocatalysis have the potential for further development (Comninellis, 2008; Robert and Malato, 2002). 


\subsection{Improved monitoring}

Techniques need to be sought to enable the wide range of potential new and existing contaminants to be detected in groundwater and surface water. These could include assays where the toxicological activity of the contaminant loading is measured rather than the identity of individual compounds.

Targeted bioassays can be effective in assessing overall toxicological activity in effluents and surface water. Muller et al. (2007) have shown that combined passive sampling and a series of bioassays was effective in monitoring polar organics in effluents.

Rodriguez-Mozaz et al. (2007) set out the advantages of using biosensors. These depend on recognition of antibodies, molecular sensors or DNA, or inference on enzyme functioning. These can be applied to pharmaceuticals and endocrine disruptors and have been applied to bisphenol A, oestrone, nonyl phenol, diethylstilbestrol, sulfamethazine, and tetracycline. Jardim et al. (in press) found that a yeast bioassay using a bioluminescent reported was more effective for monitoring for endocrine disruptors than analysis for the individual components. Bioassays can be sensitive, highly selective for compounds or activity, readily automatable and represent a cheap and fast way of screening for emerging contaminants.

Biosensors are only one example of possible alternative approaches to monitoring EGCs in groundwater. Others which have been suggested are passive samplers (Alvarez et al., 2004; Stuer-Lauridsen, 2005; Vrana et al., 2001), although there are obvious difficulties/complexities in applying these cumulative sampling methods within a regulatory framework.

\section{Conclusions}

1. A wide range of organic micropollutants is now being detected in the aqueous environment world-wide. These include nanomaterials, pesticides, pharmaceuticals, industrial additives and by-products, personal care products and fragrances, water treatment by products, flame/fire retardants and surfactants, as well as caffeine and nicotine metabolites and hormones. Many of the compounds are relatively small and/or polar molecules which can often not be effectively removed by conventional drinking water treatment using activated carbon. Many of these compounds are also toxic or are classed as endocrine disruptors. 
2. In order to assess the hazards presented by such compounds information on usage, persistence in soil and water, leachability and a robust and suitably sensitive analytical method is required. For many pesticides the above requirements are fulfilled and an assessment of risk of leaching to groundwater can be made. However, for pesticide metabolites this information can be sparse and for many emerging contaminants fate and transport data in the subsurface can be completely lacking with the majority of persistence studies directed at water treatment. A clear connection between source terms of these contaminants and groundwater-related receptors is often not well-defined to anticipate significant problems in groundwater. For compounds with no regulatory limit in groundwater, risk assessments are generally made using a toxicological approach based on estimates of PEC and PNEC. Synergistic effects from mixtures of contaminants cannot yet be fully evaluated.

3. A range of organic micropollutants from urban settings have been detected in European groundwater and surface water. Commonly detected compounds include: bisphenol A, caffeine, carbamazepine, DEET, galaxolide, ibuprofen, iopamidol, phthalates, phenyl ethoxylates, and sulfamethoxazole. Data presented in this study from the England and Wales Environment Agency's monitoring programme for organic micropollutants indicates that within the 30 most frequently detected compounds are a number of emerging contaminants such as pesticide metabolites, caffeine and DEET. Specific determinands with multiple detections include pesticides metabolites, pharmaceuticals including carbamazepine and triclosan, nicotine, food additives and alkyl phosphates.

4. Concentrations of some contaminants, such as ibuprofen and caffeine, are much higher in surface than groundwater but there are others, such as desethyl atrazine, which are higher in groundwater. This relates to different sources and pathways of entry, but it could of course also be related to different degradation rate in the subsurface. These data allow us to begin to identify important sources of emerging contaminants in groundwater in the UK; these include both diffuse sources and wastewater discharges.

5. It is clear that the risks to groundwater and its receptors are real. Many groundwater sources do not have treatment which would remove emerging contaminants and their lack of drinking water limits means that they are not currently being monitored. Much more research is needed to demonstrate whether emerging contaminants in river 
baseflow or groundwater dependent ecosystems are or could potentially have an impact.

6. Regulation of these compounds in groundwater and the wider environment will be a challenging task and require much better understanding of key contaminant properties and their distribution and behaviour in groundwater. The challenges include identifying new emerging compounds, setting appropriate standards, developing strategies to reducing inputs to the aqueous environment and applying novel monitoring methods.

\section{Acknowledgements}

This paper is published by permission of the Executive Director of the British Geological Survey.

\section{References}

Abe A. Distribution of 1,4-dioxane in relation to possible sources in the water environment. Sci Total Environ 1999;227:41-7.

AERU. Pesticide Properties Database. Agriculture \& Environment Research Unit, University of Hertfordshire, 2010.

Ahel M, Jelicic I. Phenazone analgesics in soil and groundwater below a municipal solid waste landfill. In: Daughton CG, Jones-Lepp TL, editors. Pharmaceuticals and care products in the environment. 791. American Chemical Society, Washington DC, 2001, pp. 100-15.

Ahel M, Mikac N, Cosovic B, Prohic E, Soukup V. The impact of contamination from a municipal solid waste landfill (Zagreb, Croatia) on underlying soil. Water Sci Technol 1998;37:203-10.

Ahrens L, Felitzeter S, Sturm R, Ebinghaus R. Polyfluorinated compounds in waste water treatment plant effluents and surface waters along the River Elbe, Germany. Mar Pollut Bull 2009;58:1326-33. 
Alvarez DA, Petty JD, Huckins JN, Jones-Lepp TL, Getting DT, Goddard JP, et al. Development of a passive, in situ, integrative sampler for hydrophilic organic contaminants in aquatic environments. Environ Toxicol Chem 2004;23:1640-8.

Anderson PD, D'Aco VJ, Shanahan P, Chapra SC, Buzby ME, Cunningham VL, et al. Screening analysis of human pharmaceutical compounds in US surface waters. Environ Sci Technol 2004;38:838-49.

Ashton D, Hilton M, Thomas KV. Investigating the environmental transport of human pharmaceuticals to streams in the United Kingdom. Sci Total Environ 2004;333:167-84.

Baran N, Lepiller M, Mouvet C. Agricultural diffuse pollution in a chalk aquifer (Trois Fontaines, France): Influence of pesticide properties and hydrodynamic constraints. J Hydrol 2008;358:56-69.

Baran N, Mouvet C, Negrel P. Hydrodynamic and geochemical constraints on pesticide concentrations in the groundwater of an agricultural catchment (Brevilles, France). Environ Poll 2007;148:729-38.

Baran N, Saplairoles M, Gourcy L, Denux J-P. Pesticide contamination of groundwater at the scale of a water body: example of the Ariège alluvial plain (France). European Groundwater Conference. Groundwater Protection in the EU, Madrid, 2010, pp. 77-83.

Barnes KK, Christenson SC, Kolpin DW, Focazio MJ, Furlong ET, Zaugg SD, et al. Pharmaceuticals and other organic waste water contaminants within a leachate plume downgradient of a municipal landfill. Ground Water Monit R 2004;24:119-26.

Barnes KK, Kolpin DW, Furlong ET, Zaugg SD, Meyer MT, Barber LB. A national reconnaissance of pharmaceuticals and other organic wastewater contaminants in the United States -- I) Groundwater. Sci Total Environ 2008;402:192-200.

Bartelt-Hunt S, Snow DD, Damon-Powell T, Miesbach D. Occurrence of steroid hormones and antibiotics in shallow groundwater impacted by livestock waste control facilities. J Contam Hydrol 2010;123:94-103.

Bazin I, Gadal A, Touraud E, Roig B. Hydroxy benzoate preservatives (parabens) in the environment: Data for environmental toxicity assessment. In: Fatta-Kassinos D, Bester K, Kümmerer K, editors. Xenobiotics in the urban water cycle. 16. Springer Netherlands, 2010, pp. 245-57. 
BCPC, CABI. The UK Pesticide Guide. Wallingford: CAB International \& British Crop Protection Council, 2010.

Bedding ND, McIntyre AE, Perry R, Lester JN. Organic contaminants in the aquatic environment I. Sources and occurrence. Sci Total Environ 1982;25:143-67.

Bester K, Scholes L, Wahlberg C, McArdell C. Sources and Mass Flows of Xenobiotics in Urban Water Cycles - an Overview on Current Knowledge and Data Gaps. Water Air Soil Poll Focus 2008;8:407-23.

BGS, CNA, SAPAL, WAJ, DMR, PSU. Protecting groundwater beneath wastewater recharge sites. British Geological Survey, Keyworth, 1998.

Blackburn MA, Kirby SJ, Waldock MJ. Concentrations of alkyphenol polyethoxylates entering UK estuaries. Mar Pollut Bull 1999;38:109-18.

Bolong N, Ismail AF, Salim MR, Matsuura T. A review of the effects of emerging contaminants in wastewater and options for their removal. Desalination 2009;239:229-46.

Boorman GA. Drinking water disinfection byproducts: review and approach to toxicity evaluation. Environ Health Persp 1999;107:207-17.

Borgert CJ, Price B, Wells CS, Simon GS. Evaluating chemical interaction studies for mixture risk assessment. Human Ecol Risk Assess 2001;7:259-306.

Bound JP, Voulvoulis N. Predicted and measured concentrations for selected pharmaceuticals in UK rivers: Implications for risk assessment. Water Res 2006;40:2885-92.

Boxall ABA, Fogg LA, Blackwell PA, Kay P, Pemberton EJ. Review of veterinary medicines in the environment. Environment Agency Bristol, 2002.

Brausch JM, Rand GM. A review of personal care products in the aquatic environment: Environmental concentrations and toxicity. Chemosphere 2010;82:1518-32.

Bristol Water. Briefing on metaldehyde, 30/1/2009.

Buerge IJ, Buser H-R, Kahle M, MuÌ ller MD, Poiger T. Ubiquitous occurrence of the artificial sweetener acesulfame in the aquatic environment: an ideal chemical marker of domestic wastewater in groundwater. Environ Sci Technol 2009;43:4381-5.

Buerge IJ, Buser H-R, Muller MD, Poiger T. Behavior of the polycyclic musks HHCB and AHTN in lakes, two potential anthropogenic markers for domestic wastewater in surface waters. Environ Sci Technol 2003;37:5636-44. 
Buerge IJ, Buser H-R, Poiger T, Müller MD. Occurrence and fate of the cytostatic drugs cyclophosphamide and ifosfamide in wastewater and surface waters Environ Sci Technol 2006;40:7242-50.

Buszka P, Yeskis D, Kolpin DW, Furlong E, Zaugg S, Meyer M. Waste-indicator and pharmaceutical compounds in landfill-leachate-affected ground water near Elkhart, Indiana, 2000-2002. Bull Environ Con Tox 2009;82:653-9.

Buttiglieri G, Peschka M, Frömel T, Müller J, Malpei F, Seel P, et al. Environmental occurrence and degradation of the herbicide n-chloridazon. Water Res 2009;43:2865-73.

Byrns G. The fate of xenobiotic organic compounds in wastewater treatment plants. Water Res 2001;35:2523-33.

Carballa M, Omil F, Lema JM, Llompart M, García-Jares C, Rodríguez I, et al. Behavior of pharmaceuticals, cosmetics and hormones in a sewage treatment plant. Water Res 2004;38:2918-26.

Carlsson C, Johansson A-K, Alvan G, Bergman K, Kühler T. Are pharmaceuticals potent environmental pollutants?: Part I: Environmental risk assessments of selected active pharmaceutical ingredients. Sci Total Environ 2006;364:67-87.

Carpy SA, Kobel W, Doe J. Health risk of low-dose pesticide mixtures: A review of the 1985-1998 literature on combination toxicology and health risk assessment. J Toxicol Env Heal B 2000;3:1-25.

Chang SY, Liao C-H. Analysis of glyphosate, glufosinate and aminomethylphosphonic acid by capillary electrophoresis with indirect fluorescence detection. J Chromatogr A 2002;959:309-15.

CHBR. Pharmaceuticals in the environment, information for assessing risk Centre for Coastal and Environmental Health and Biomolecular Research Charleston, USA, 2009.

Clara M, Strenn B, Kreuzinger N. Carbamazepine as a possible anthropogenic marker in the aquatic environment: investigations on the behaviour of carbamazepine in wastewater treatment and during groundwater infiltration. Water Res 2004;38:947-54.

Comninellis C, Kapalka A, Malato S, Parsons SA, Poulios I, Mantzavinos D. Advanced oxidation processes for water treatment: advances and trends for R\&D. J Chem Technol Biotech 2008;83:769-76. 
Cooper ER, Siewicki TC, Phillips K. Preliminary risk assessment database and risk ranking of pharmaceuticals in the environment. Sci Total Environ 2008;398:26-33.

Corbel V, Stankiewicz M, Pennetier C, Fournier D, Stojan J, Girard E, et al. Evidence for inhibition of cholinesterases in insect and mammalian nervous systems by the insect repellent deet. BMC Biology 2009;7:47.

Cordy GE, Duran NL, Bouwer H, Rice RC, Furlong ET, Zaugg SD, et al. Do pharmaceuticals, pathogens, and other organic waste water compounds persist when waste water Is used for recharge? Ground Water Monit R 2004;24:58-69.

Cronin MTD, Walker JD, Jaworska JS, Comber MHI, Watts CD, Worth AP. Use of QSARs in international decision-making frameworks to predict ecologic effects and environmental fate of chemical substances. Environ Health Persp 2003;111:1376-90.

Cunningham VL, Binks SP, Olson MJ. Human health risk assessment from the presence of human pharmaceuticals in the aquatic environment. Regul Toxicol Pharm 2009;53:39-45.

Daughton CG. Non-regulated water contaminants: emerging research. Environ Impact Asses 2004;24:711-32.

Debska J, Kot-Wasik A, Namiesnik J. Fate and analysis of pharmaceutical residues in the aquatic environment. Crit Rev Anal Chem 2004;34:51-67.

Díaz-Cruz MS, Barceló D. Trace organic chemicals contamination in ground water recharge. Chemosphere 2008;72:333-42.

Drewes JE, Heberer T, Rauch T, Reddersen K. Fate of pharmaceuticals during ground water recharge. Ground Water Monit R 2003;23:64-72.

EC. Drinking Water Directive 98/83/EC. European Commission, 1998.

EC. Priority Substances Directive 2008/105/EC. European Commission, 2008.

EC. Review of priority substances under the WFD, 2011.

EC. Water Framework Directive 2000/60/EC. European Commission, 2000.

Eckel WP, Ross B, Isensee RK. Pentobarbital found in ground water. Ground Water $1993 ; 31: 801-4$. 
Eckstein G, Sherk GW. Alternative strategies for managing pharmaceutical and personal care products in water resources. Texas Tech University, Centre for Water Policy and Law, 2011.

Eljarrat E, Barceló D. Priority lists for persistent organic pollutants and emerging contaminants based on their relative toxic potency in environmental samples. TrACTrend Anal Chem 2003;22:655-65.

EMEA. Guideline on the environmental risk assessment of medicinal products for human use. European Medicines Agency London, 2005.

ENDS. River dioxins increased by triclosan. ENDS Rep 2010;425:32.

Environment Agency. Investigation of PFOS and other perfluorochemicals in groundwater and surface water in England and Wales. Environment Agency, Bristol, 2007.

Environment Agency. Pesticides Report for 2007. Environment Agency, Bristol, 2008.

Environment Agency. The Environment Agency’s position on Metaldehyde, Jan 2010.

Escher BI, Bramaz N, Ort C. JEM Spotlight: Monitoring the treatment efficiency of a full scale ozonation on a sewage treatment plant with a mode-of-action based test battery. $\mathrm{J}$ Environ Monit 2009;11:1836-46.

Escher BI, Bramaz N, Quayle P, Rutishauser S, Vermeirssen ELM. Monitoring of the ecotoxicological hazard potential by polar organic micropollutants in sewage treatment plants and surface waters using a mode-of-action based test battery. J Environ Monit 2008;10:622-31.

Escher BI, Pronk W, Suter MJF, Maurer M. Monitoring the removal efficiency of pharmaceuticals and hormones in different treatment processes of source-separated urine with bioassays. Environ Sci Technol 2006;40:5095-101.

EUGRIS. Portal for Soil and Water Management in Europe:- Emerging Pollutants. EUGRIS, 2011.

Farré Ml, Pérez S, Kantiani L, Barceló D. Fate and toxicity of emerging pollutants, their metabolites and transformation products in the aquatic environment. TrAC 2008;27:9911007.

Fatta-Kassinos D, Bester K, Kümmerer K, Bazin I, Gadal A, Touraud E, et al. Hydroxy benzoate preservatives (parabens) in the environment: data for environmental toxicity 
assessment. In: Fatta-Kassinos D, Bester K, Kümmerer K, editors. Xenobiotics in the urban water cycle. 16. Springer Netherlands, 2010, pp. 245-57.

Fava L, Orru MA, Crobe A, Caracciolo AB, Bottoni P, Funari E. Pesticide metabolites as contaminants of groundwater resources: assessment of the leaching potential of endosulfan sulfate, 2,6-dichlorobenzoic acid, 3,4-dichloroaniline, 2.4-dichlorophenol and 4-chloro-2-methylphenol. Microchem J 2005;79:207-11.

Feijtel T, Boeije G, Matthies M, Young A, Morris G, Gandolfi C, et al. Development of a geography-referenced regional exposure assessment tool for European rivers-GREATER. Contribution to GREAT-ER \# 1. Chemosphere 1997;34:2351-73.

Fent K, Weston AA, Caminada D. Ecotoxicology of human pharmaceuticals. Aquat Toxicol 2006;76:122-59.

Ferrari B, Paxéus N, Giudice RL, Pollio A, Garric J. Ecotoxicological impact of pharmaceuticals found in treated wastewaters: study of carbamazepine, clofibric acid, and diclofenac. Ecotox Environ Safe 2003;55:359-70.

Ford RA, Domeyer B, Easterday O, Maier K, Middleton J. Criteria for development of a database for safety evaluation of fragrance ingredients. Regul Toxicol Pharm 2000;31:166-81.

Fromme H, Otto T, Pilz K. Polycyclic musk fragrances in different environmental compartments in Berlin (Germany). Water Res 2001;35:121-8.

Garrett P, Moreau M, Lowry J. MTBE as a ground water contaminant. NWWA/API Conference on Petroleum Hydrocarbons and Organic Chemicals in Ground Water: Prevention, Detection and Restoration. National Water Well Association, Dublin, Ohio, Houston, Texas, 1986, pp. 227-38.

Gasser G, Rona M, Voloshenko A, Shelkov R, Tal N, Pankratov I, et al. Quantitative evaluation of tracers for quantification of wastewater contamination of potable water sources. Environ Sci Technol 2010;44:3919-25.

Germolec DR, Yang RSH, Ackermann MF, Rosenthal GJ, Boorman GA, Blair P, et al. Toxicology studies of a chemical mixture of 25 groundwater contaminants : II. Immunosuppression in B6C3F1 mice. Fund Appl Toxicol 1989;13:377-87. 
Gevao B, Semple KT, Jones KC. Bound pesticide residues in soils: a review. Environ Poll 2000;108:3-14.

Giacomazzi S, Cochet N. Environmental impact of diuron transformation: a review. Chemosphere 2004;56:1021-32.

Gibs J, Stackelberg PE, Furlong ET, Meyer M, Zaugg SD, Lippincott RL. Persistence of pharmaceuticals and other organic compounds in chlorinated drinking water as a function of time. Sci Total Environ 2007;373:240-49.

Giger G, Schaffner C, Kohler HP. Benzotriazole and tolyltriazole as aquatic contaminants. 1. Input and occurrence in rivers and lakes. Environ Sci Technol 2006;40:7186-92.

Glassmeyer ST, Kolpin DW, Furlong E, Focazio MJ. Environmental presence and persistence of pharmaceuticals: an overview. In: Aga DS, editor. Fate of pharmaceuticals in the environment and in water treatment systems. CRC Press, Boca Raton, 2008, pp. 352.

Godfrey E, Woessner W, Benotti MJ. Pharmaceuticals in on-site sewage effluent and ground water, Western Montana. Ground Water 2007;45:263-71.

Grice HC, Goldsmith LA. Sucralose--an overview of the toxicity data. Food Chem Toxicol 2000;38:1-6.

Haarstad K, Ludvigsen GH. Ten years of pesticide monitoring in Norwegian ground water. Ground Water Monit R 2007;27:75-89.

Haith DA. Variability of pesticide loads to surface water. J Water Pollut Cont Fed 1985;57:1062-67.

Halling-Sørensen B, Nors Nielsen S, Lanzky PF, Ingerslev F, Holten Lützhøft HC, Jørgensen SE. Occurrence, fate and effects of pharmaceutical substances in the environment- A review. Chemosphere 1998;36:357-93.

Hamscher G, Hartung J. Veterinary antibiotics in dust: sources, environmental concentrations, and possible health hazards. In: Kümmerer K, editor. Pharmaceuticals in the environment. Springer-Verlag, Berlin, 2008.

Hancock TC, Sandstrom MW, Vogel JR, Webb RMT, Bayless ER, Barbash JE. Pesticide fate and transport throughout unsaturated zones in five agricultural settings, USA. J Environ Qual 2008;37:1086-100. 
Harada K, Saito N, Sasaki K, Inoue K, Koizumi A. Perfluorooctane sulfonate contamination of drinking water in the Tama River, Japan: Estimated effects on resident serum levels. Bull Environ Con Tox 2003;71:31-6.

Heberer T, Dünnbier U, Reilich C, Stan H-J. Detection of drugs and drug metabolites in ground water samples of a drinking water treatment plant Fresen Environ Bull 1997;6:438-43.

Heberer T, Feldmann D. Contribution of effluents from hospitals and private households to the total loads of diclofenac and carbamazepine in municipal sewage effluents--modeling versus measurements. J Hazard Mater 2005;122:211-8.

Heberer T. Occurrence, fate, and assessment of polycyclic musk residues in the aquatic environment of urban areas - A review. Acta Hydroch Hydrob 2002a;30:227-43.

Heberer T. Occurrence, fate, and removal of pharmaceutical residues in the aquatic environment: a review of recent research data. Toxicol Lett 2002b;131:5-17.

Heberer T. Tracking persistent pharmaceutical residues from municipal sewage to drinking water. J Hydrol 2002;266:175-89.

Hekster FM, Laane RWPM, Voogt P. Environmental and toxicity effects of perfluoroalkylated substances. Rev Environ Contamin Toxicol 2003;179:99-121.

Hilal SH, Bornander LL, Carreira LA. Hydration equilibrium constants of aldehydes, ketones and quinazolines. QSAR \& Combin Sci 2005;24:631-38.

Hildebrandt A, Lacorte S, Barcelo D. Assessment of priority pesticides, degradation products, and pesticide adjuvants in groundwaters and top soils from agricultural areas of the Ebro river basin. Anal Bioanal Chem 2007;387:1459-68.

Hilton M, Thomas K, Ashton D. Targetted monitoring programme for pharmaceuticals in the aquatic environment. Environment Agency, Bristol, 2003.

Holm JV, Rügge K, Bjerg PL, Christensen TH. Occurrence and distribution of pharmaceutical organic compounds in the groundwater downgradient of a landfill (Grindsted, Denmark). Environ Sci Technol 1995;29:1415-20.

Hooper K, McDonald TA. The PBDEs: an emerging environmental challenge and another reason for breast-milk monitoring programs. Environ Health Persp 2000;108:387-92. 
Horii Y, Reiner JL, Loganathan BG, Senthil Kumar K, Sajwan K, Kannan K. Occurrence and fate of polycyclic musks in wastewater treatment plants in Kentucky and Georgia, USA. Chemosphere 2007;68:2011-20.

Hu X, Zhou Q, Luo Y. Occurrence and source analysis of typical veterinary antibiotics in manure, soil, vegetables and groundwater from organic vegetable bases, northern China. Environ Poll 2010;158:2992-8.

Jackson R. Recognising emerging environmental problems: The case of chlorinated solvents in groundwater. Technol Cult 2004;45:55-79.

Jacobsen CS, Sørensen SR, Juhler RK, Brüsch W, Aamand J. Emerging contaminants in Danish groundwater, 2005.

Jardim WF, Montagner CC, Pescara IC, Umbuzeiro GA, Di Dea Bergamasco AM, Eldridge ML, et al. An integrated approach to evaluate emerging contaminants in drinking water. Separ Purific Technol in press.

Jaworska J, Dimitrov S, Nikolova N, Mekenyan O. Probabilistic assessment of biodegradability based on metabolic pathways: CATABOL System. SAR QSAR Environ Res 2002;13:307-323.

Jeon H-K, Chung Y, Ryu J-C. Simultaneous determination of benzophenone-type UV filters in water and soil by gas chromatography-mass spectrometry. J Chromatogr A 2006;1131:192-202.

Jobling S, Reynolds T, White R, Parker MG, Sumpter JP. A variety of environmentally persistent chemicals, including some phthalate plasticizers, are weakly estrogenic. Environ Health Persp 1995;103:582-7.

Johnson AC, Belfroid A, Di Corcia A. Estimating steroid oestrogen inputs into activated sludge treatment works and observations on their removal from the effluent. Sci Total Environ 2000;256:163-73.

Johnson AC, Jürgens MD, Williams RJ, Kümmerer K, Kortenkamp A, Sumpter JP. Do cytotoxic chemotherapy drugs discharged into rivers pose a risk to the environment and human health? An overview and UK case study. J Hydrol 2008;348:167-75. 
Johnson AC, Keller V, Williams RJ, Young A. A practical demonstration in modelling diclofenac and propranolol river water concentrations using a GIS hydrology model in a rural UK catchment. Environ Poll 2007a;146:155-65.

Johnson AC, Williams RJ, Simpson P, Kanda R. What difference might sewage treatment performance make to endocrine disruption in rivers? Environ Poll 2007b;147:194-202.

Johnson AC, Williams RJ. A model to estimate influent and effluent concentrations of estradiol, estrone, and ethinylestradiol at sewage treatment works. Environ Sci Technol 2004;38:3649-58.

Jones OAH, Lester JN, Voulvoulis N. Pharmaceuticals: a threat to drinking water? Trends Biotechnol. 2005;23:163-7.

Jones OAH, Voulvoulis N, Lester JN. Aquatic environmental assessment of the top 25 English prescription pharmaceuticals. Water Res 2002;36:5013-22.

Joss A, Zabczynski S, Göbel A, Hoffmann B, Löffler D, McArdell CS, et al. Biological degradation of pharmaceuticals in municipal wastewater treatment: Proposing a classification scheme. Water Research 2006;40:1686-96.

Jürgens MD, Holthaus KIE, Johnson AC, Smith JJL, Hetheridge M, Williams RJ. The potential for estradiol and ethinylestradiol degradation in English rivers. Environ Toxicol Chem 2002;21:480-8.

Kasprzyk-Hordern B, Dinsdale RM, Guwy AJ. The occurrence of pharmaceuticals, personal care products, endocrine disruptors and illicit drugs in surface water in South Wales, UK. Water Res 2008;42:3498-518.

Kavanaugh MC. Unregulated and emerging chemical contaminants: technical and institutional challenges. P Water Environ Fed 2003;WEFTEC: Session 1-10:1-19.

Kavlock RJ, Ankley G, Blancato J, Breen M, Conolly R, Dix D, et al. Computational toxicology - A state of the science mini review. Toxicol Sci 2008;103:14-27.

Khadam IM, Kaluarachchi JJ. Multi-criteria decision analysis with probabilistic risk assessment for the management of contaminated ground water. Environ Impact Asses 2003;23:683-721. 
Kim K-R, Owens G, Kwon S-I, So K-H, Lee D-B, Ok YS. Occurrence and environmental fate of veterinary antibiotics in the terrestrial environment. Water Air Soil Poll 2011;214:163-74.

Kjaer, J, Olsen P, Henriksen T, Ullum M. Leaching of metribuzin metabolites and the associated contamination of a sandy Danish aquifer. Environ Sci Technol 2005;39:837481 .

Kolodziej EP, Harter T, Sedlak DL. Dairy wastewater, aquaculture, and spawning fish as sources of steroid hormones in the aquatic environment. Environ Sci Technol 2004;38:6377-84.

Kolpin DW, Barbash JE, Gilliom RJ. Pesticides in ground water of the United States, 19921996. Ground Water 2000;38:858-63.

Kolpin DW, Schnoebelen DJ, Thurman EM. Degradates provide insight to spatial and temporal trends of herbicides in ground water. Ground Water 2004;42:601-8.

Kolpin DW, Thurman EM, Linhart SM. The environmental occurrence of herbicides: The importance of degradates in ground water. Arch Environ Con Tox 1998;35:385-90.

Kostich MS, Batt AL, Glassmeyer ST, Lazorchak JM. Predicting variability of aquatic concentrations of human pharmaceuticals. Sci Total Environ 2010;408:4504-10.

Kostich MS, Lazorchak JM. Risks to aquatic organisms posed by human pharmaceutical use. Sci Total Environ 2008;389:329-39.

Kreuzinger N, Clara M, Strenn B, Vogel JR. Investigation on the behaviour of selected pharmaceuticals in the groundwater after infiltration of treated wastewater. Water Sci Technol 2004;50:221-8.

Kühne R, Ebert R-U, Schüürmann G. Estimation of compartmental half-lives of organic compounds - Structural similarity versus EPI-Suite. QSAR \& Combin Sci 2007;26:54249.

Kümmerer K. Strategies for reducing the input of pharmaceuticals into the environment. In: Kümmerer K, editor. Pharmaceuticals in the environment. Springer-Verlag, Berlin, 2008.

Lacorte S, Latorre A, Guillamon M, Barcelo D. Nonylphenol, octylphenol, and bisphenol A in groundwaters as a result of agronomic practices. Sci World J 2002;2:1095-100. 
Laganà A, Bacaloni A, De Leva I, Faberi A, Fago G, Marino A. Occurrence and determination of herbicides and their major transformation products in environmental waters. Anal Chim Acta 2002;462:187-98.

Lai KM, Johnson KL, Scrimshaw MD, Lester JN. Binding of waterborne steroid estrogens to solid phases in river and estuarine systems. Environ Sci Technol 2000;34:3890-4.

Lam M, Young C, Brain R, Johnson D, Hanson M, Wilson C, et al. Aquatic persistence of eight pharmaceuticals in a microcosm study. Environ Toxicol Chem 2004;23:1431-40.

Lapworth DJ, Gooddy DC. Source and persistence of pesticides in a semi-confined chalk aquifer of southeast England, Environ Poll 2006;144: 1031--44.

Lapworth DJ, Baran N, Stuart ME, Lopez B, Ward RS. Emerging contaminants: a review of occurence, sources and fate in groundwater. Environ Poll submitted.

Larsson DGJ, de Pedro C, Paxéus N. Effluent from drug manufactures contains extremely high levels of pharmaceuticals. J Hazard Mater 2007;148:751-5.

Larsson DGJ. Drug production facilities - an overlooked discharge source for pharmaceuticals to the environment. In: Kümmerer K, editor. Pharmaceuticals in the environment. Springer-Verlag, Berlin, 2008.

Latorre A, Lacorte S, Barceló D. Presence of nonylphenol, octyphenol and bisphenol a in two aquifers close to agricultural, industrial and urban areas. Chromatographia 2003;57:111-6.

Lindström A, Buerge IJ, Poiger T, Bergqvist P-A, Müller MD, Buser H-R. Occurrence and environmental behavior of the bactericide triclosan and its methyl derivative in surface waters and in wastewater. Environ Sci Technol 2002;36:2322-9.

Lioy PJ. Assessing total human exposure to contaminants. A multidisciplinary approach. Environ Sci Technol 1990;24:938-45.

Liu Z-h, Kanjo Y, Mizutani S. A review of phytoestrogens: Their occurrence and fate in the environment. Water Res 2010;44:567-77.

Löffler D, Römbke J, Meller M, Ternes T. Environmental fate of pharmaceuticals in water/sediment systems. Environ Sci Technol 2005;39:2509-18.

Loos R, Gawlik BM, Locoro G, Rimaviciute E, Contini S, Bidoglio G. EU-wide survey of polar organic persistent pollutants in European river waters. Environ Poll 2009;157:5618. 
Loos R, Locoro G, Comero S, Contini S, Schwesig D, Werres F, et al. Pan-European survey on the occurrence of selected polar organic persistent pollutants in ground water. Water Res 2010;44:4115-26.

Mason PJ, Foster IDL, Carter AD, Walker A, Higginbotham S, Jones RL, et al. Relative importance of point source contamination of surface waters: River Cherwell catchment monitoring study. In: Del Re AAM, Brown C, Capri E, Errera G, Evans SP, Trevisan M, editors. Human and environmental exposure to xenobiotics. La Goliardica Pavese, Pavia, 1999, pp. 405-12.

Matthews HB, Eustis SL, Haseman J. Toxicity and carcinogenicity of chronic exposure to tris(2-chloroethyl)phosphate. Toxicol Sci 1993;20:477-85.

Maurer M, Escher BI, Richle P, Schaffner C, Alder AC. Elimination of b-blockers in sewage treatment plants. Water Res 2007;41:1614-22.

Meerts IA, Letcher RJ, Hoving S, Marsh G, Bergman A, Lemmen JG, et al. In vitro estrogenicity of polybrominated diphenyl ethers, hydroxylated PDBEs, and polybrominated bisphenol A compounds. Environ Health Persp 2001;109:399-407.

Mezcua M, Gómez MJ, Ferrer I, Aguera A, Hernando MD, Fernández-Alba AR. Evidence of 2,7/2,8-dibenzodichloro-p-dioxin as a photodegradation product of triclosan in water and wastewater samples. Anal Chim Acta 2004;524:241-7.

Miller KJ, Meek J. Helena Valley ground water: pharaceuticals, personal care products, endocrine disruptors (PPCPs) and microbial indicators of fecal contamination. Montana Bureau of Mines and Geology, 2006.

Mitch WA, Sharp JO, Trussell RR, Valentine RL, Alvarez-Cohen L, Sedlak DL. NNitrosodimethylamine (NDMA) as a drinking water contaminant: A review. Environ Eng Sci 2003;20:389-404.

Moldovan Z. Occurrences of pharmaceutical and personal care products as micropollutants in rivers from Romania. Chemosphere 2006;64:1808-17.

Montagnani DB, Puddefoot J, Davie TJA, Vinson GP. Environmentally persistent oestrogenlike substances in UK river systems. Water Environ J 1996;10:399-406.

Montana Dept of Agriculture. Groundwater monitoring for pesticides and nitrate in shallow aquifers of the Helena Valley, Montana, 2006. 
Montgomery-Brown J, Reinhard M. Occurrence and behavior of alkylphenol polyethoxylates in the environment. Environ Eng Sci 2003;20:471-86.

Moore M, Greenway S, Farris J, Guerra B. Assessing caffeine as an emerging environmental concern using conventional approaches. Arch Environ Con Tox 2008;54:31-5.

Moran MJ, Zogorski JS, Squillace PJ. Chlorinated solvents in groundwater of the United States. Environ Sci Technol 2006;41:74-81.

Moran MJ, Zogorski JS, Squillace PJ. MTBE and gasoline hydrocarbons in ground water of the United States. Ground Water 2005;43:615-27.

Muller R, Tang JYM, Thier R, Mueller JF. Combining passive sampling and toxicity testing for evaluation of mixtures of polar organic chemicals in sewage treatment plant effluent. $\mathrm{J}$ Environ Monit 2007;9:105-110.

Musolff A, Leschik S, Möder M, Strauch G, Reinstorf F, Schirmer M. Temporal and spatial patterns of micropollutants in urban receiving waters. Environ Poll 2009;157:3069-77.

Nagel JE, Fuscaldo JT, Fireman P. Paraben allergy. J Am Med Ass 1977;237:1594-5.

Nghiem LD, Schäfer AI, Elimelech M. Nanofiltration of hormone mimicking trace organic contaminants. Separ Sci Technol 2005a;40:2633-2649.

Nghiem LD, Schäfer AI, Elimelech M. Pharmaceutical retention mechanisms by nanofiltration membranes. Environ Sci Technol 2005b;39:7698-705.

Nghiem LD, Schäfer AI. Critical risk points of nanofiltration and reverse osmosis processes in water recycling applications. Desalination 2006;187:303-12.

Nikolaou A, Meric S, Fatta D. Occurrence patterns of pharmaceuticals in water and wastewater environments. Anal Bioanal Chem 2007;387:1225-34.

Oishi S. Effects of propyl paraben on the male reproductive system. Food and Chemical Toxicology 2002;40:1807-13.

Oppel J, Broll G, Löffler D, Meller M, Römbke J, Ternes T. Leaching behaviour of pharmaceuticals in soil-testing-systems: a part of an environmental risk assessment for groundwater protection. Sci Total Environ 2004;328:265-73.

Osenbrück K, Gläser H-R, Knöller K, Weise SM, Möder M, Wennrich R, et al. Sources and transport of selected organic micropollutants in urban groundwater underlying the city of Halle (Saale), Germany. Water Res 2007;41:3259-70. 
Pal A, Gin KY-H, Lin AY-C, Reinhard M. Impacts of emerging organic contaminants on freshwater resources: Review of recent occurrences, sources, fate and effects. Sci Total Environ 2010;408:6062-9.

Parsons SA, Boxall ABA, Sinclair CJ, Ramwell C. Pesticide degradates of concern to the drinking water community. AWWA Research Foundation, Denver, 2008.

Pérez S, Barceló D. Fate and occurrence of X-ray contrast media in the environment. Anal Bioanal Chem 2007;387:1235-46.

Persson K, Destouni G. Propagation of water pollution uncertainty and risk from the subsurface to the surface water system of a catchment. J Hydrol 2009;377:434-44.

Petrović M, Eljarrat E, Lopez de Alda MJ, Barceló D. Endocrine disrupting compounds and other emerging contaminants in the environment: A survey on new monitoring strategies and occurrence data. Anal Bioanal Chem 2004;378:549-62.

Petrović M, Gonzalez S, Barceló D. Analysis and removal of emerging contaminants in wastewater and drinking water. TrAC 2003;22:685-96.

Pomati F, Castiglioni S, Zuccato E, Fanelli R, Vigetti D, Rossetti C, et al. Effects of a complex mixture of therapeutic drugs at environmental levels on human embryonic cells. Environ Sci Technol 2006;40:2442-7.

Pomati F, Orlandi C, Clerici M, Luciani F, Zuccato E. Effects and interactions in an environmentally relevant mixture of pharmaceuticals. Toxicol Sci 2008;102:129-37.

Power M, Attrill MJ, Thomas RM. Trends in agricultural pesticide (atrazine, lindane, simazine) concentrations in the Thames Estuary. Environ Poll 1999;104:31-9.

Poynton HC, Vulpe CD. Ecotoxicogenomics: emerging technologies for emerging contaminants. J Am Water Resour As 2009;45:83-95.

Purdom CE, Hardiman PA, Bye VVJ, Eno NC, Tyler CR, Sumpter JP. Estrogenic effects of effluents from sewage treatment works. Chem Ecol 1994;8:275-85.

Putschew A, Wischnack S, Jekel M. Occurrence of triiodinated X-ray contrast agents in the aquatic environment. Sci Total Environ 2000;255:129-34.

Rahman F, Langford KH, Scrimshaw MD, Lester JN. Polybrominated diphenyl ether (PBDE) flame retardants. Sci Total Environ 2001;275:1-17. 
Relyea R. A cocktail of contaminants: how mixtures of pesticides at low concentrations affect aquatic communities. Oecologia 2009;159:363-76.

Ricart M, Guasch H, Alberch M, Barceló D, Bonnineau C, Geiszinger A, et al. Triclosan persistence through wastewater treatment plants and its potential toxic effects on river biofilms. Aquat Toxicol 2010;100:346-53.

Richardson ML, Bowron JM. The fate of pharmaceutical chemicals in the aquatic environment. J Pharm Pharmacol 1985;37:1-12.

Richardson SD, Ternes TA. Water analysis: emerging contaminants and current issues. Anal Chem 2011;83:4614-4648.

Richardson SD. Disinfection by-products and other emerging contaminants in drinking water. TrAC-Trend Anal Chem 2003;22:666-84.

Richardson SD. Water analysis: emerging contaminants and current issues. Anal Chem 2007;79:4295-324.

Ritter L, Solomon K, Sibley P, Hall K, Keen P, Mattu G, et al. Sources, pathways, and relative risks of contaminants in surface water and groundwater: a perspective prepared for the Walkerton Inquiry. J Toxicol Env Heal A 2002;65:1 - 142.

Robert D, Malato S. Solar photocatalysis: a clean process for water detoxification. Sci Total Environ 2002;291:85-97.

Roberts $\mathrm{PH}$, Thomas KV. The occurrence of selected pharmaceuticals in wastewater effluent and surface waters of the lower Tyne catchment. Sci Total Environ 2006;356:143-53.

Rodriguez-Mozaz S, Lopez de Alda MJ, Barceló D. Advantages and limitations of on-line solid phase extraction coupled to liquid chromatography-mass spectrometry technologies versus biosensors for monitoring of emerging contaminants in water. J Chromatog A 2007;1152:97-115.

Rosal R, Rodríguez A, Perdigón-Melón JA, Petre A, García-Calvo E, Gómez MJ, et al. Occurrence of emerging pollutants in urban wastewater and their removal through biological treatment followed by ozonation. Water Res 2010;44:578-88.

Rose CL, McKay WA, Ambidge PF. PCDD and PCDF levels in river systems in England and Wales, UK. Chemosphere 1994;29:1279-92. 
Rudel RA, Melly SJ, Geno PW, Sun G, Brody JG. Identification of alkylphenols and other estrogenic phenolic compounds in wastewater, septage, and groundwater on Cape Cod, Massachusetts. Environ Sci Technol 1998;32:861-9.

Rutishauser BV, Pesonen M, Escher BI, Ackermann GE, Aerni H-R, Suter MJF, et al. Comparative analysis of estrogenic activity in sewage treatment plant effluents involving three in vitro assays and chemical analysis of steroids. Environ Toxicol Chem 2004;23:857-64.

Sabljic A. QSAR models for estimating properties of persistent organic pollutants required in evaluation of their environmental fate and risk. Chemosphere 2001;43:363-75.

Sacher F, Lange FT, Brauch H-J, Blankenhorn I. Pharmaceuticals in groundwaters: Analytical methods and results of a monitoring program in Baden-Württemberg, Germany. J Chromatogr A 2001;938:199-210.

Saito N, Sasaki K, Nakatome K, Harada K, Yoshinaga T, Koizumi A. Perfluorooctane sulfonate concentrations in surface water in Japan. Arch Environ Con Tox 2003;45:14958.

Sanderson H, Brain RA, Johnson DJ, Wilson CJ, Solomon KR. Toxicity classification and evaluation of four pharmaceuticals classes: antibiotics, antineoplastics, cardiovascular, and sex hormones. Toxicology 2004a;203:27-40.

Sanderson H, Johnson DJ, Reitsma T, Brain RA, Wilson CJ, Solomon KR. Ranking and prioritization of environmental risks of pharmaceuticals in surface waters. Regul Toxicol Pharm 2004b;39:158-83.

Santos JL, Aparicio I, Alonso E. Occurrence and risk assessment of pharmaceutically active compounds in wastewater treatment plants. A case study: Seville city (Spain). Environ Int 2007;33:596-601.

Sarmah AK, Meyer MT, Boxall ABA. A global perspective on the use, sales, exposure pathways, occurrence, fate and effects of veterinary antibiotics (VAs) in the environment. Chemosphere 2006;65:725-59.

Schäfer AI, Nghiem LD, Waite TD. Removal of the natural hormone estrone from aqueous solutions using nanofiltration and reverse osmosis. Environ Sci Technol 2002;37:182-8. 
Schriks M, Heringa MB, van der Kooi MME, de Voogt P, van Wezel AP. Toxicological relevance of emerging contaminants for drinking water quality. Water Res 2010;44:46176.

Schulman LJ, Sargent EV, Naumann BD, Faria EC, Dolan DG, Wargo JP. A human health risk assessment of pharmaceuticals in the aquatic environment. Human Ecol Risk Assess 2002;8:657-80.

Schwab BW, Hayes EP, Fiori JM, Mastrocco FJ, Roden NM, Cragin D, et al. Human pharmaceuticals in US surface waters: A human health risk assessment. Regul Toxicol Pharm 2005;42:296-312.

Schwarzenbach RP, Escher BI, Fenner K, Hofstetter TB, Johnson CA, von Gunten U, et al. The challenge of micropollutants in aquatic systems. Science 2006;313:1072-7.

Seed J, Brown RP, Olin SS, Foran JA. Chemical mixtures: current risk assessment methodologies and future directions. Regul Toxicol Pharm 1995;22:76-94.

Seiler R, Zaugg SD, Thomas JM, Howcroft DL. Caffeine and pharmaceuticals as indicators of waste water contamination in wells. Ground Water 1999;37:405-10.

Sinclair CJ, Boxall ABA. Assessing the ecotoxicity of pesticide transformation products. Environ Sci Technol 2003;37:4617-25.

Sinclair CJ, van Beinum W, Adams C, Bevan R, Levy L, Parsons S, et al. A desk study on pesticide metabolites, degradation and reaction products to inform the Inspectorate's position on monitoring requirements. Final Report for Drinking Water Inspectorate. Food and Environment Research Agency, York, 2010.

Singer AC, Nunn MA, Gould EA, Johnson AC. Potential risks associated with the proposed widespread use of Tamiflu. Environ Health Persp 2007;115:102-6.

Smith EA, Oehme FW. Acrylamide and polyacrylamide: a review of production, use, environmental fate and neurotoxicity. Rev Environ Health 1991;9:215-28.

Snyder SA, Adham S, Redding AM, Cannon FS, DeCarolis J, Oppenheimer J, et al. Role of membranes and activated carbon in the removal of endocrine disruptors and pharmaceuticals. Desalination 2007;202:156-81. 
Snyder SA, Westerhoff P, Yoon Y, Sedlak DL. Pharmaceuticals, personal care products, and endocrine disruptors in water: Implications for the water industry. Environ Eng Sci 2003;20:449-69.

Soares A, Guieysse B, Jefferson B, Cartmell E, Lester JN. Nonylphenol in the environment: A critical review on occurrence, fate, toxicity and treatment in wastewaters. Environ Int 2008;34:1033-49.

Sodré F, Locatelli M, Jardim W. Occurrence of emerging contaminants in Brazilian drinking waters: A sewage-to-tap issue. Water Air Soil Poll 2009;206:57-67.

Soni MG, Taylor SL, Greenberg NA, Burdock GA. Evaluation of the health aspects of methyl paraben: a review of the published literature. Food Chem Toxicol 2002;40:133573.

SRC. Interactive PhysProp database. SRC Inc, Syracuse, New York, 2010.

Stackelberg PE, Gibs J, Furlong ET, Meyer MT, Zaugg SD, Lippincott RL. Efficiency of conventional drinking-water-treatment processes in removal of pharmaceuticals and other organic compounds Sci Total Environ 2007;377:255-72.

Standley L, Rudel R, Swartz C, Attfield K, Christian J, Erickson M, et al. Wastewatercontaminated groundwater as a source of endogenous hormones and pharmaceuticals to surface water ecosystems. Environ Toxicol Chem 2008;27:2457-68.

Stangroom SJ, Collins CD, Lester JN. Sources of organic micropollutants to lowland rivers. Environ Technol 1998;19:643-66.

Straub JO. Deterministic and probabilistic environmental risk assessment for diazepam. In: Kümmerer K, editor. Pharmaceuticals in the environment. Springer-Verlag, Berlin, 2008.

Stuart ME, Klinck BA. A catalogue of leachate quality for selected landfills from newly industrialised countries. British Geological Survey Technical Report WC/98/49, Keyworth, 1998.

Stuer-Lauridsen F. Review of passive accumulation devices for monitoring organic micropollutants in the aquatic environment. Environ Poll 2005;136:03-524.

Stumm-Zollinger E, Fair GM. Biodegradation of steroid hormones. J Water Pollut Cont Fed 1965;37:1506-10. 
Teijon G, Candela L, Tamoh K, Molina-Díaz A, Fernández-Alba AR. Occurrence of emerging contaminants, priority substances (2008/105/CE) and heavy metals in treated wastewater and groundwater at Depurbaix facility (Barcelona, Spain). Sci Total Environ 2010;408:3584-95.

Ternes $\mathrm{T}$, von Gunten U. Editorial to special issue in Water Research: Emerging contaminants in water. Water Res 2010;44:351.

Ternes TA, Hirsch R. Occurrence and behavior of X-ray contrast media in sewage facilities and the aquatic environment. Environ Sci Technol 2000;34:2741-8.

Ternes TA, Joss A, Siegrist H. Scrutinizing pharmaceuticals and personal care products in wastewater treatment. Environ Sci Technol 2004;38:392A-9A.

Ternes TA, Meisenheimer M, McDowell D, Sacher F, Brauch H-J, Haist-Gulde B, et al. Removal of pharmaceuticals during drinking water treatment. Environ Sci Technol 2002;36:3855-63.

Thi PTP, Cho C-W, Yun Y-S. Environmental fate and toxicity of ionic liquids: A review. Water Res 2010;44:352-72.

Thomas KV, Hurst MR, Matthiessen P, Sheahan D, Williams RJ. Toxicity characterisation of organic contaminants in stormwaters from an agricultural headwater stream in South East England. Water Res 2001;35:2411-6.

US EPA. National Primary Drinking Water Regulations. United States Environmental Protection Agency, 2010.

Van Stempvoort DR, Roy JW, Brown SJ, Bickerton G. Artificial sweeteners as potential tracers in groundwater in urban environments. J Hydrol 2011;401:126-33.

Vega M, Pardo R, Barrado E, Debán L. Assessment of seasonal and polluting effects on the quality of river water by exploratory data analysis. Water Res 1998;32:3581-92.

Verlicchi P, Galletti A, Petrovic M, Barceló D. Hospital effluents as a source of emerging pollutants: an overview of micropollutants and sustainable treatment options. J Hydrol 2010;389:416-28.

Verliefde A, Cornelissen E, Amy G, Van der Bruggen B, van Dijk H. Priority organic micropollutants in water sources in Flanders and the Netherlands and assessment of removal possibilities with nanofiltration. Environ Poll 2007;146:281-9. 
Verma B, Headley JV, Robarts RD. Behaviour and fate of tetracycline in river and wetland waters on the Canadian Northern Great Plains. J Environ Sci Heal A 2007;42:109 -17.

Voutsa D, Hartmann P, Schaffner C, Giger W. Benzotriazoles, alkylphenols and bisphenol A in municipal wastewaters and in the Glatt River, Switzerland. Environ Sci Pollut Res 2006;13:333-41.

Vrana B, Popp P, Paschke A, Schüürmann G. Membrane-enclosed sorptive coating. An integrative passive sampler for monitoring organic contaminants in water. Anal Chem 2001;73:5191-5200.

Vulliet E, Cren-Olivé C. Screening of pharmaceuticals and hormones at the regional scale, in surface and groundwaters intended to human consumption. Environ Poll 2011;159:292934.Walker JD, Carlsen L, Hulzebos E, Simon-Hettich B. Global government applications of analogues, SARs and QSARs to predict aquatic toxicity, chemical or physical properties, environmental fate parameters and health effects of organic chemicals. SAR QSAR Environ Res 2002;13:607-16.

Watanabe N, Bergamaschi BA, Loftin KA, Meyer MT, Harter T. Use and environmental occurrence of antibiotics in freestall dairy farms with manured forage fields. Environ Sci Technol 2010;44:6591-600.

Watanabe N, Harter TH, Bergamaschi BA. Environmental occurrence and shallow ground water detection of the antibiotic monensin from dairy farms. J Environ Qual 2008;37:S78-S85.

Water UK. Wastewater treatment and recycling. Water UK, London, 2006. http://www.water.org.uk/home/news/press-releases/wastewater-pamphlet/wastewaterweb--2-.pdf

Water UK. Technical briefing note: metaldehyde. Water UK, London, 2009.

Watkinson AJ, Murby EJ, Kolpin DW, Costanzo SD. The occurrence of antibiotics in an urban watershed: From wastewater to drinking water. Sci Total Environ 2009;407:271123.

Weil ED, Zhu W, Patel N, Mukhopadhyay SM. A systems approach to flame retardancy and comments on modes of action. Polym Degrad Stabil 1996;54:125-36. 
Wells MJM. Log DOW: key to understanding and regulating wastewater-derived contaminants. Environ Chem 2006;3:439-49.

Westerhoff P, Yoon Y, Snyder S, Wert E. Fate of endocrine-disruptor, pharmaceutical, and personal care product chemicals during simulated drinking water treatment processes. Environ Sci Technol 2005;39:6649-63.

White R, Jobling S, Hoare SA, Sumpter JP, Parker MG. Environmentally persistent alkylphenolic compounds are estrogenic. Endocrinology 1994;135:175-182.

Whitehouse CR, Boullata J, McCauley LA. The potential toxicity of artificial sweeteners. AAOHN 2008;56:251-9.

Whiteside TS, Hilal SH, Carreira LA. Estimation of phosphate ester hydrolysis rate constants. I. Alkaline hydrolysis. QSAR \& Combin Sci 2006;25:123-33.

WHO. Drinking Water Quality Guidelines for Selected Herbicides. Vol 27. Geneva: World Health Organisation, 1987.

Williams GM, Harrison I, Carlick CA, Crowley O. Changes in enantiomeric fraction as evidence of natural attenuation of mecoprop in a limestone aquifer. J Contam Hydrol 2003;64:253-67.

Wilson SC, Duarte-Davidson R, Jones KC. Screening the environmental fate of organic contaminants in sewage sludges applied to agricultural soils: 1. The potential for downward movement to groundwaters. Sci Total Environ 1996;185:45-57.

Worrall F, Wooff DA, Seheult AH, Coolen FPA. New approaches to assessing the risk of groundwater contamination by pesticides. Journal of the Geological Society 2000;157:877-84.

Yamamoto H, Nakamura Y, Moriguchi S, Nakamura Y, Honda Y, Tamura I, et al. Persistence and partitioning of eight selected pharmaceuticals in the aquatic environment: Laboratory photolysis, biodegradation, and sorption experiments. Water Res 2009;43:351-62.

Yang RSH, Hong HL, Boorman GA. Toxicology of chemical mixtures: experimental approaches, underlying concepts, and some results. Toxicol Lett 1989;49:183-97.

Ying G-G, Williams B, Kookana R. Environmental fate of alkylphenols and alkylphenol ethoxylates--a review. Environ Int 2002;28:215-26. 
Zhang Z, Hibberd A, Zhou JL. Analysis of emerging contaminants in sewage effluent and river water: Comparison between spot and passive sampling. Anal Chim Acta 2008;607:37-44.

Zorita S, Mårtensson L, Mathiasson L. Occurrence and removal of pharmaceuticals in a municipal sewage treatment system in the south of Sweden. Sci Total Environ 2009;407:2760-70.

Zuccato E, Castiglioni S, Bagnati R, Chiabrando C, Grassi P, Fanelli R. Illicit drugs, a novel group of environmental contaminants. Water Res 2008;42:961-8.

Zwiener C. Occurrence and analysis of pharmaceuticals and their transformation products in drinking water treatment. Anal Bioanal Chem 2007;387:1159-62. 
Table 1 Pesticides used in the UK over more than 50,000 ha in 2008 with octanol/water partition coefficients lower than metaldehyde

\begin{tabular}{|l|r|}
\hline Compound & Log $\mathrm{K}_{\mathrm{ow}}$ \\
\hline Diquat & -4.6 \\
\hline Mepiquat chloride & -3.55 \\
\hline Chlormequat chloride & -3.47 \\
\hline Glyphosate & -3.2 \\
\hline Prohexadione-calcium & -2.9 \\
\hline Clopyralid & -2.63 \\
\hline Picloram & -1.92 \\
\hline Dicamba & -1.88 \\
\hline Metsulfuron-methyl & -1.7 \\
\hline Thifensulfuron-methyl & -1.7 \\
\hline Amidosulfuron & -1.56 \\
\hline Quinmerac & -1.41 \\
\hline Propamocarb hydrochloride & -1.3 \\
\hline Florasulam & -1.22 \\
\hline Imazaquin & -1.09 \\
\hline 2,4-D & -0.83 \\
\hline MCPA & -0.81 \\
\hline Mesosulfuron-methyl & -0.48 \\
\hline Trinexapac-ethyl & -0.29 \\
\hline MCPP-P & 0.02 \\
\hline Metaldehyde & 0.12 \\
\hline
\end{tabular}


Table 2 Summaries of selected studies finding pesticide metabolites in groundwater

\begin{tabular}{|c|c|c|c|c|}
\hline Area & Pesticides detected & Metabolites detected & Process & Ref erence \\
\hline $\begin{array}{l}\text { Hesse, } \\
\text { Germany }\end{array}$ & Chloridazon & desphenyl-chloridazon & $\begin{array}{l}\text { Parent and metabolite } \\
\text { in STW effluent, } \\
\text { surface water and } \\
\text { groundwater }\end{array}$ & $\begin{array}{l}\text { Buttiglieri et al. } \\
\text { (2009) }\end{array}$ \\
\hline $\begin{array}{l}\text { Rome } \\
\text { province, } \\
\text { Italy }\end{array}$ & 2,4-D, bentazone, MCPA, & 8-hydroxybentazone & Survey & $\begin{array}{l}\text { Laganà et al. } \\
(2002)\end{array}$ \\
\hline $\begin{array}{l}\text { Lincolnshire, } \\
\text { UK }\end{array}$ & MCPP (chiral mixture) & 4-chloro-2-methylphenol & $\begin{array}{l}\text { Change in enantiomeric } \\
\text { ratio during degradation }\end{array}$ & $\begin{array}{l}\text { Williams et al. } \\
(2003)\end{array}$ \\
\hline Kent, UK & Diuron, Atrazine, Simazine & DCPMU, DCPU, DCA & Research project & $\begin{array}{l}\text { Lapworth and } \\
\text { Gooddy (2006) }\end{array}$ \\
\hline Denmark & $\begin{array}{l}\text { Atrazine, bentazone, dichlorprop, } \\
\text { MCPA, MCPP, simazine }\end{array}$ & $\begin{array}{l}\text { 2,6-dichlorobenzamide (dichlobenil) } \\
\text { deethylatrazine, deisopropylatrazine, } \\
\text { hydroxyatrazine, ethylenethiurea } \\
\text { (mancozeb), desamino-diketo- } \\
\text { metribuzin, diketo- metribuzin, }\end{array}$ & $\begin{array}{l}\text { National monitoring } \\
\text { programme }\end{array}$ & $\begin{array}{l}\text { Jacobsen et al. } \\
(2005)\end{array}$ \\
\hline Denmark & Metribuzin & $\begin{array}{l}\text { desamino-diketo- metribuzin, diketo- } \\
\text { metribuzin }\end{array}$ & Research project & Kjaer et al.(2005) \\
\hline Norway & $\begin{array}{l}27 \text { including bentazone, clopyralid, } \\
\text { dichlorprop, dimethoate, isoproturon, } \\
\text { linuron, mecoprop, metalaxyl, } \\
\text { metribuzin, propachlor, terbutylazine }\end{array}$ & $\begin{array}{l}\text { desethyl atrazine, 2,6- } \\
\text { dichlorobenzamide, AMPA }\end{array}$ & Monitoring & $\begin{array}{l}\text { Haarstad and } \\
\text { Ludvigsen (2007) }\end{array}$ \\
\hline
\end{tabular}


Table 3 Key metabolites assessed as having leaching potential from Figure 2

\begin{tabular}{|c|c|c|c|}
\hline Parent compound & Key metabolite & $\mathbf{D T}_{50}$ & $\mathbf{K}_{\mathbf{o c}}$ \\
\hline \multirow[t]{2}{*}{ Chlorothalonil } & $\begin{array}{l}\text { 2-amido-3,5,6-trichlo-4-cyanobenzenesulphonic } \\
\text { acid }\end{array}$ & 121 & 10 \\
\hline & 3-carbamyl-2,4,5-trichlorobenzoic acid & 103 & 77 \\
\hline \multirow[t]{2}{*}{ Cymoxanil } & 2-cyano-2-methoxyiminoacetic acid & 2.8 & 9 \\
\hline & $\begin{array}{l}\text { 3-ethyl-4-(methoxyamino)-2,5-dioxoimidazolidine- } \\
\text { 4-carboxamide }\end{array}$ & 11.2 & 21.6 \\
\hline Cyproconazole & 1H-1,2,4-triazol-1-ylacetic acid & 15 & 8 \\
\hline Diflufenican & 2-(3-trifluoromethylphenoxy)nicotinic acid & 10.6 & 13 \\
\hline \multirow[t]{2}{*}{ Florasulam } & $\begin{array}{l}\text { 5-(aminosulfonyl)-1H-1,2,4-triazole-3-carboxylic } \\
\text { acid }\end{array}$ & 328 & 83 \\
\hline & $\begin{array}{l}\text { N-(2,6-difluorophenyl)-8-fluoro-5- } \\
\text { hydroxy[1,2,4]triazolo[1,5-c]pyrimidine-2- } \\
\text { sulfonamide }\end{array}$ & 23 & 21 \\
\hline \multirow[t]{2}{*}{ Flufenacet } & FOE oxalate & 11 & 11 \\
\hline & FOE sulphonic acid & 230 & 10 \\
\hline Fluoxastrobin & HEC-5725-des-chlorophenyl & 67 & 60 \\
\hline Fluroxypyr & 4-amino-3,5-dichloro-6-fluoro-2-pyridinol & 37 & 4 \\
\hline Iodosulfuron-methyl- $\mathrm{Na}$ & 2-amino-4-methoxy-6-methyl-1,3,5-triazine & 181 & 97.7 \\
\hline \multirow[t]{2}{*}{ Mesosulfuron-methyl } & 4,6-dimethoxypyrimidine-2-yl-urea & 48 & 3 \\
\hline & Mesosulfuron & 53 & 68 \\
\hline Metaldehyde & Acetaldehyde & 18.5 & 1.5 \\
\hline Metsulfuron-methyl & Saccharin & 150 & 5.2 \\
\hline Thiram & N,N dimethyl carbamosulfonic acid & 38 & 33 \\
\hline \multirow[t]{2}{*}{ Tribenuron-methyl } & N-methyl triazine amine & 165 & 89 \\
\hline & Saccharin & 105 & 5.2 \\
\hline
\end{tabular}


Table 4 Examples of models to calculate properties required to predict the fate and transport of contaminants

\begin{tabular}{|l|l|l|l|}
\hline Model & Description & Parameters predicted & Reference \\
\hline EPI-Suite & Fragment constant & $\begin{array}{l}\text { KOW, solubility, } \\
\text { hydrolysis rate }\end{array}$ & $\begin{array}{l}\text { (Kavlock et al., } \\
\text { 2008) }\end{array}$ \\
\hline KNN & Atom-centred fragments & $\begin{array}{l}\text { indirect photolysis, } \\
\text { biodegradation, and } \\
\text { hydrolysis }\end{array}$ & (Kühne et al.,2007) \\
\hline SPARC & $\begin{array}{l}\text { Fundamental chemical } \\
\text { structure theory } \\
\text { (LFER \& PMO) }\end{array}$ & $\begin{array}{l}\text { Thermodyanamic } \\
\text { properties } \\
\text { Physicochemical } \\
\text { properties }\end{array}$ & $\begin{array}{l}\text { (Hilal et al., 2005; } \\
\text { Whiteside et al., } \\
\text { 2006) }\end{array}$ \\
\hline CATABOL & $\begin{array}{l}\text { Degradation simulator using } \\
\text { hierarchy of abiotic and } \\
\text { enzymatic reactions }\end{array}$ & $\begin{array}{l}\text { Biotransformation } \\
\text { pathways and } \\
\text { metabolites }\end{array}$ & $\begin{array}{l}\text { (Jaworska et al., } \\
\text { 2002) }\end{array}$ \\
\hline $\begin{array}{l}\text { SAR/QSAR } \\
\text { type }\end{array}$ & $\begin{array}{l}\text { Molecular connectivity } \\
\text { Structural activity relationship }\end{array}$ & $\begin{array}{l}\text { Physical and chemical } \\
\text { properties, } \\
\text { environmental fate, } \\
\text { ecological effects and } \\
\text { health effects of organic }\end{array}$ & $\begin{array}{l}\text { (Sabljic, 2001; } \\
\text { Walker et al., 2002; } \\
\text { Cronin et al., 2003) }\end{array}$ \\
\hline
\end{tabular}


Table 5 Organic micropollutants detected in UK surface water (LOD = limit of detection; TW = wastewater treatment works)

\begin{tabular}{|c|c|c|c|}
\hline Site & Source & Compounds detected & Reference \\
\hline England and Wales & $\begin{array}{l}\text { Contaminated } \\
\& \text { control sites }\end{array}$ & polychlorinated dibenzo-p-dioxins and dibenzofurans detected in all sediments sampled & Rose et al. (1994) \\
\hline $\begin{array}{l}\text { Thames in south west } \\
\text { London and rural river }\end{array}$ & WTW & $\begin{array}{l}\text { ibuprofen, paracetamol and salbutamol quantified in all samples. } \\
\text { mefenamic acid (NSAID) in } 70 \% \text { of samples. } \\
\text { propanolol ( } \beta \text {-blocker) }<\text { LOD }\end{array}$ & $\begin{array}{l}\text { Bound and } \\
\text { Voulvoulis (2006) }\end{array}$ \\
\hline Tyne Estuary & WTW & $\begin{array}{l}\text { clotrimazole, dextropropoxyphene, erythromycin, ibuprofen, propanalol, tamoxifen, } \\
\text { trimethoprim quantified } \\
\text { clofibric acid, diclofenac, mefenamic acid, paracetamol }<\text { LOD }\end{array}$ & $\begin{array}{l}\text { Roberts and Thomas } \\
\text { (2006) }\end{array}$ \\
\hline $\begin{array}{l}\text { Tees, Mersey, Aire } \\
\text { river and estuary }\end{array}$ & Industry? & APEs detected above threshold & $\begin{array}{l}\text { Blackburn et al. } \\
\text { (1999) }\end{array}$ \\
\hline $\begin{array}{l}\text { Taff \& Ely, South } \\
\text { Wales }\end{array}$ & WTW & $\begin{array}{l}\text { trimethoprim, erythromycin, amoxicillin, paracetamol, tramadol, codeine, naproxen, } \\
\text { ibuprofen, diclofenac, carbamazepine, gabapentin most frequently detected } \\
41 \text { others detected including illicit drugs }\end{array}$ & $\begin{array}{l}\text { Kasprzyk-Hordern et } \\
\text { al. (2008) }\end{array}$ \\
\hline Inland streams & WTW & $\begin{array}{l}\text { ibuprofen, mefamic acid, diclofenac, propanalol, dextropropoxyphene, erythromycin, } \\
\text { trimethoprim, acetyl-sulfamethazole detected } \\
\text { paracetamol, lofepramine not detected }\end{array}$ & Ashton et al. (2004) \\
\hline Ouse, west Sussex & WTW & $\begin{array}{l}\text { bisphenol A, oestrone, } 17 \beta \text {-oestodiol consistently detected } \\
\text { propanalol, sulfamethoxazole, carbamazepine, indomethacine, diclofenac variably detected } \\
\text { mebeverine, thioridazine, tamoxifen, meclofenanic acid }<\text { LOD }\end{array}$ & Zhang et al. (2008) \\
\hline UK & & Diuron & Alvarez et al. (2004) \\
\hline $\begin{array}{l}\text { Stream, Tunbridge } \\
\text { Wells }\end{array}$ & $\begin{array}{l}\text { Storm event, } \\
\text { Fruit growing }\end{array}$ & simazine, diuron, NP, endosulfan sulphate, pendimethalin & Thomas et al. (2001) \\
\hline Thames, 1988-1997 & & atrazine, simazine, lindane & Power et al. (1999) \\
\hline
\end{tabular}


Table 6 Summary of emerging contaminant detections in European groundwater

\begin{tabular}{|c|c|c|c|}
\hline Location & Source & Compounds detected (Range of concentrations $\left(\mathrm{ng} \mathrm{L}^{-1}\right)$ ) & Reference \\
\hline $\begin{array}{l}\text { Eastern } \\
\text { England }\end{array}$ & STW & $\begin{array}{l}\text { Pharmaceuticals (<20-max): Ibuprofen (5044), erythromycin (1022), dextropropoxyphene (682), diclofenac } \\
\text { (568), mefanamic acid (366), propanolol (215), acetyl-sulfamethoxazole (239), trimethoprim (42) }\end{array}$ & $\begin{array}{l}\text { Hilton et al. } \\
(2003)\end{array}$ \\
\hline $\begin{array}{l}\text { Leipzig, } \\
\text { Germany }\end{array}$ & STW & Bisphenol A $(\sim 7000)$, NP $(\sim 1000)$, caffeine $(\sim 140)$, carbamazepine $(\sim 90)$, tonalide $(\sim 6)$, galoxalide $(\sim 2.8)$ & $\begin{array}{l}\text { Musolff et } \\
\text { al.(2009) }\end{array}$ \\
\hline $\begin{array}{l}\text { Halle, } \\
\text { Germany }\end{array}$ & STW & Bisphenol A(<1-1136), carbamazepine $(<2-83)$, galaxolide (3-19) & $\begin{array}{l}\text { Osenbrück et al. } \\
(2007)\end{array}$ \\
\hline $\begin{array}{l}\text { Baden- } \\
\text { Würtemberg, } \\
\text { Germany }\end{array}$ & STW & $\begin{array}{l}\text { Maximum concentrations: amidotrizoic acid (1100), carbamazepine (900), diclofenac (590), sotalol (560), } \\
\text { sulfamethoxazole (410), iopamidol (300), anhydro-erythromycin (49), phenazone (25). }\end{array}$ & $\begin{array}{l}\text { Sacher et al. } \\
(2001)\end{array}$ \\
\hline
\end{tabular}


Table 7 Data from UK Environment Agency Monitoring for compounds with $>20$ detections in groundwater over the period 1992 to 2009

\begin{tabular}{|c|c|c|c|c|c|}
\hline Type & Name & Detects & Sites & Max conc $(\mu \mathrm{g} / \mathrm{L})$ & Use \\
\hline \multirow{10}{*}{$\begin{array}{l}\text { Pharmaceuticals and } \\
\text { personal care products }\end{array}$} & DEET & 280 & 280 & 6.5 & Insect repellent \\
\hline & Propylparaben & 68 & 68 & 5.5 & Personal care \\
\hline & Methylparaben & 44 & 44 & 5 & Personal care \\
\hline & Trimipramine & 34 & 34 & 0.26 & Antidepressant \\
\hline & Carbamazepine & 32 & 32 & 3.6 & Antiepileptic \\
\hline & Oxybenzone & 32 & 32 & 70.4 & Personal care \\
\hline & 1,3-Dicyclohexylurea & 27 & 27 & 0.41 & Blood pressure/hypertension \\
\hline & Isopropyl myristate & 22 & 22 & 0.39 & Personal care \\
\hline & Triclosan & 22 & 22 & 2.11 & Antibacterial \\
\hline & Coumarin & 20 & 20 & 0.42 & Anticoagulant \\
\hline \multirow{9}{*}{$\begin{array}{l}\text { Lifestyle and food } \\
\text { additives }\end{array}$} & Caffeine & 722 & 720 & 4.5 & Coffee and tea \\
\hline & Nicotine & 107 & 107 & 8.07 & Tobacco ingredient \\
\hline & 2,6-di-t-butyl-4-methylphenol (BHT) & 106 & 106 & 7.0 & Food additive \\
\hline & $\begin{array}{l}\text { 2,6-di(t-butyl)-4-hydroxy-4-methyl-2,5- } \\
\text { cyclohexadien-1-one (BHT analogue) }\end{array}$ & 79 & 79 & 4.2 & Food additive \\
\hline & 1(3H)-Isobenzofuranone (phthalide) & 59 & 56 & 9.3 & Food additive \\
\hline & Cotinine & 40 & 40 & 0.4 & Nicotine metabolite \\
\hline & Vanillin & 31 & 31 & 1.08 & Food additive \\
\hline & p-acetylacetophenone & 30 & 30 & 9.42 & Food additive \\
\hline & Dimethyldisufide & 22 & 22 & 9.48 & Food additive \\
\hline \multirow{4}{*}{$\begin{array}{l}\text { Alkyl phosphates and } \\
\text { resins }\end{array}$} & Tributylphosphate & 450 & 450 & 2.5 & Solvent, plasticiser \& anti-foaming \\
\hline & Bisphenol A & 209 & 206 & 9.3 & Resin precursor \\
\hline & 2-ethylhexyl diphenyl phosphate & 68 & 68 & 2.7 & Flame retardant plasticiser \\
\hline & Tris(2-dichloroethyl)phosphate & 54 & 54 & 4.9 & Flame retardant plasticiser \\
\hline
\end{tabular}




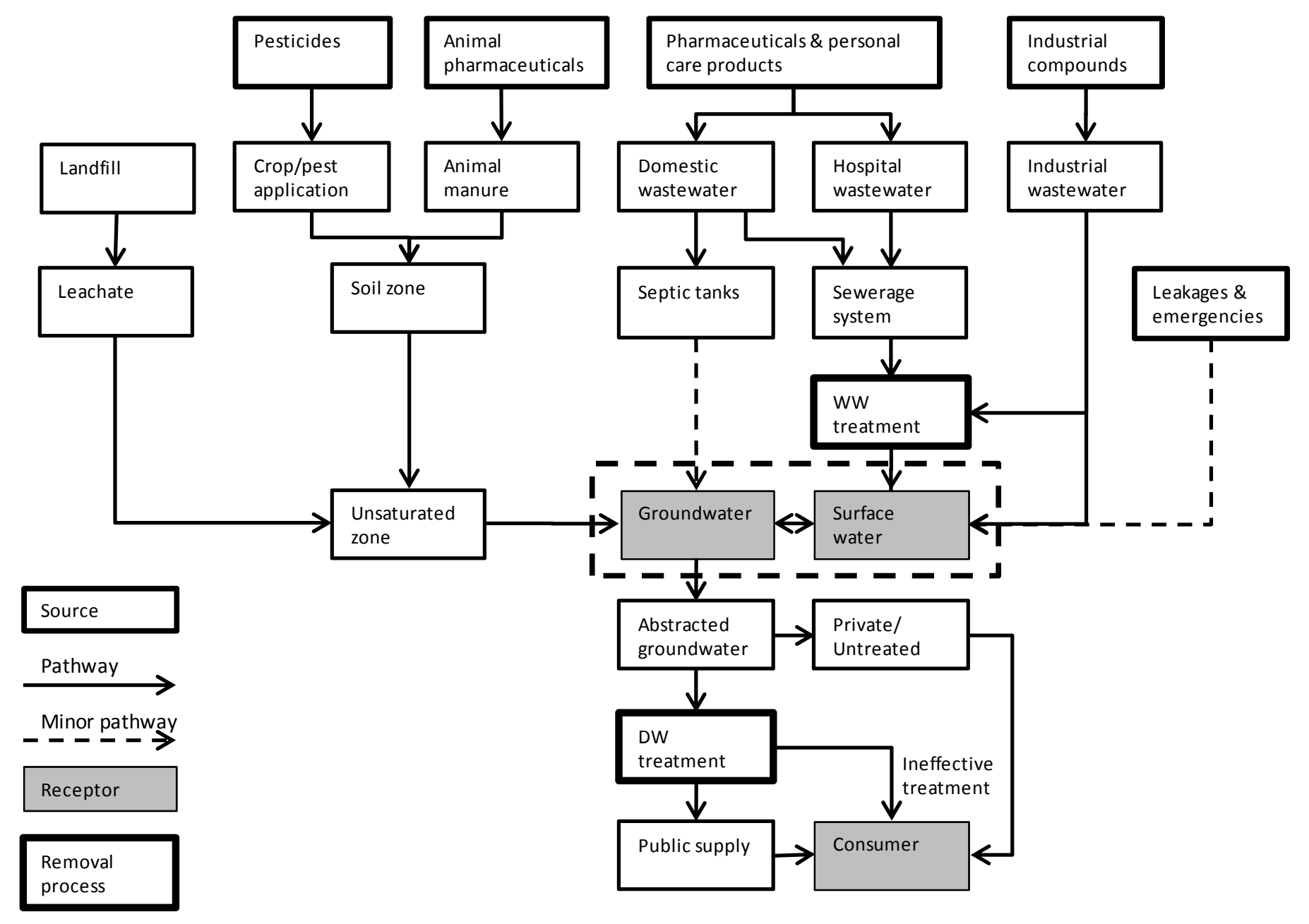

Figure 1Sources (bold) and pathways for emerging contaminants to reach various receptors (grey) 


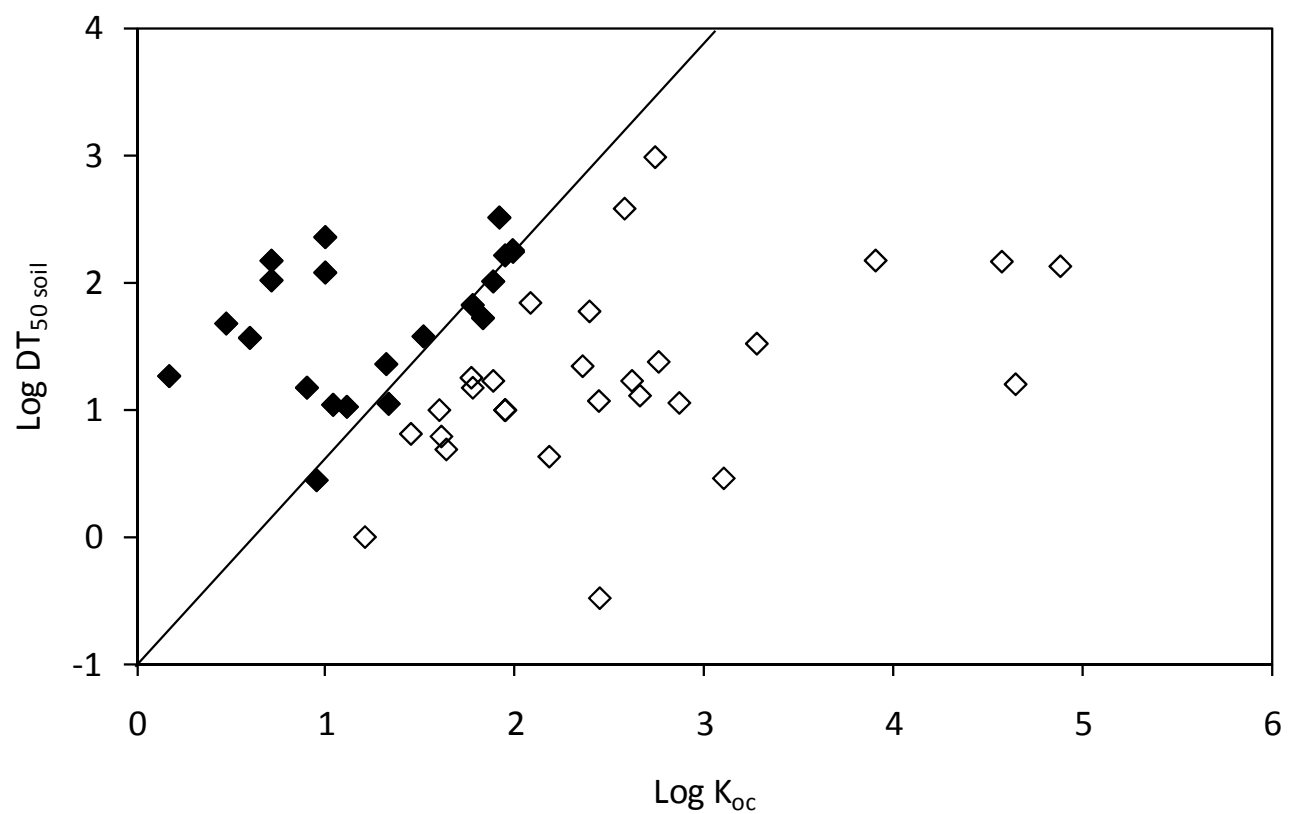

Figure 2 Classification of leaching probability of all compounds using $\mathrm{K}_{\mathrm{oc}}$ and $\mathrm{DT}_{50}$ (after Worrall et al, 2000). Compounds with solid symbols assessed as leachers 

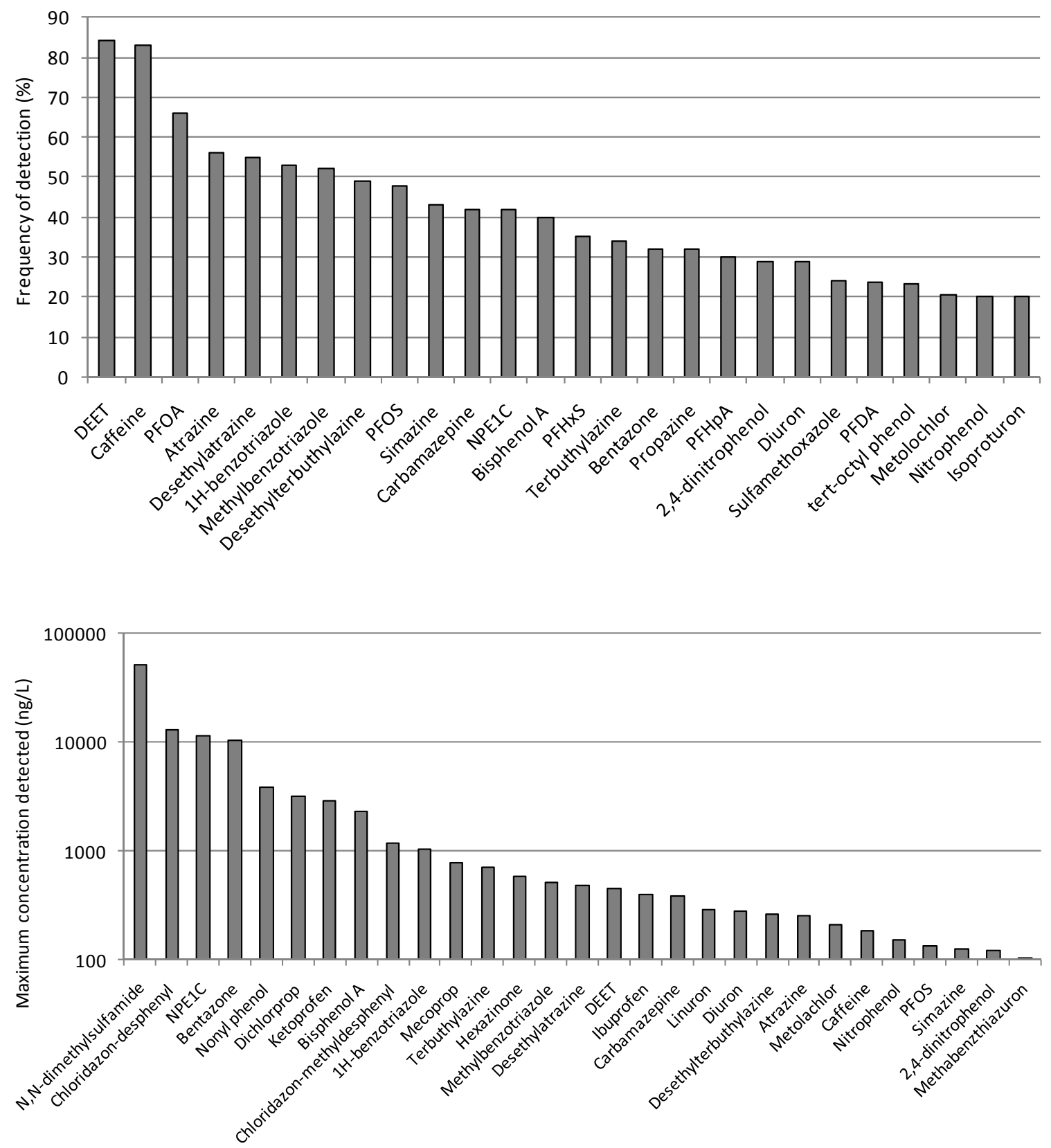

Figure 3 Frequency of detection and maximum detected concentrations in European groundwater (from Loos et al., 2010) 


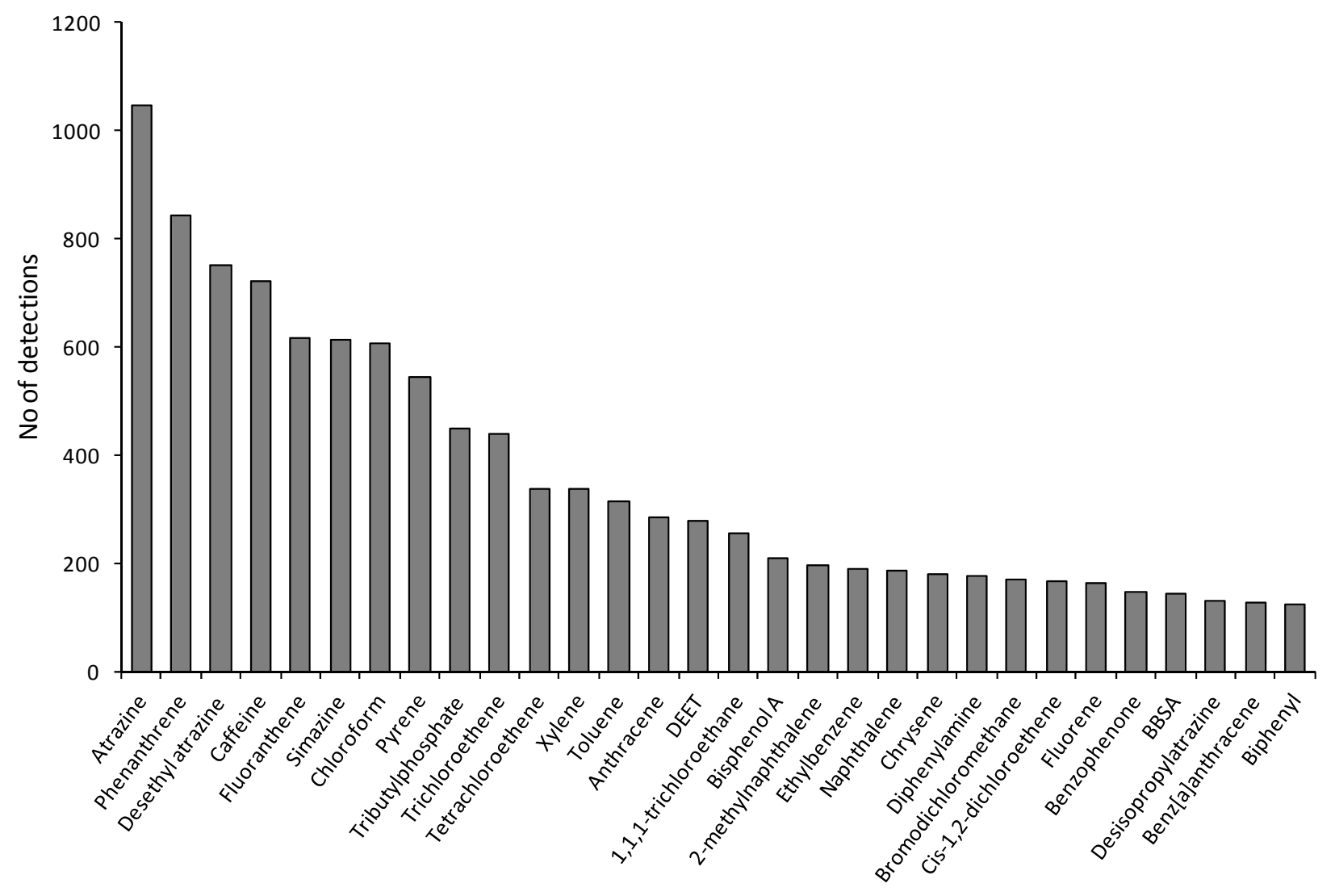

Figure 4 The top 30 most frequently detected compounds in the Environment Agency groundwater organic micropollutant database $($ DEET $=$ N.N-dimethyl-toluamide, $B B S A=$ N-butyl benzene sulphonamide) 


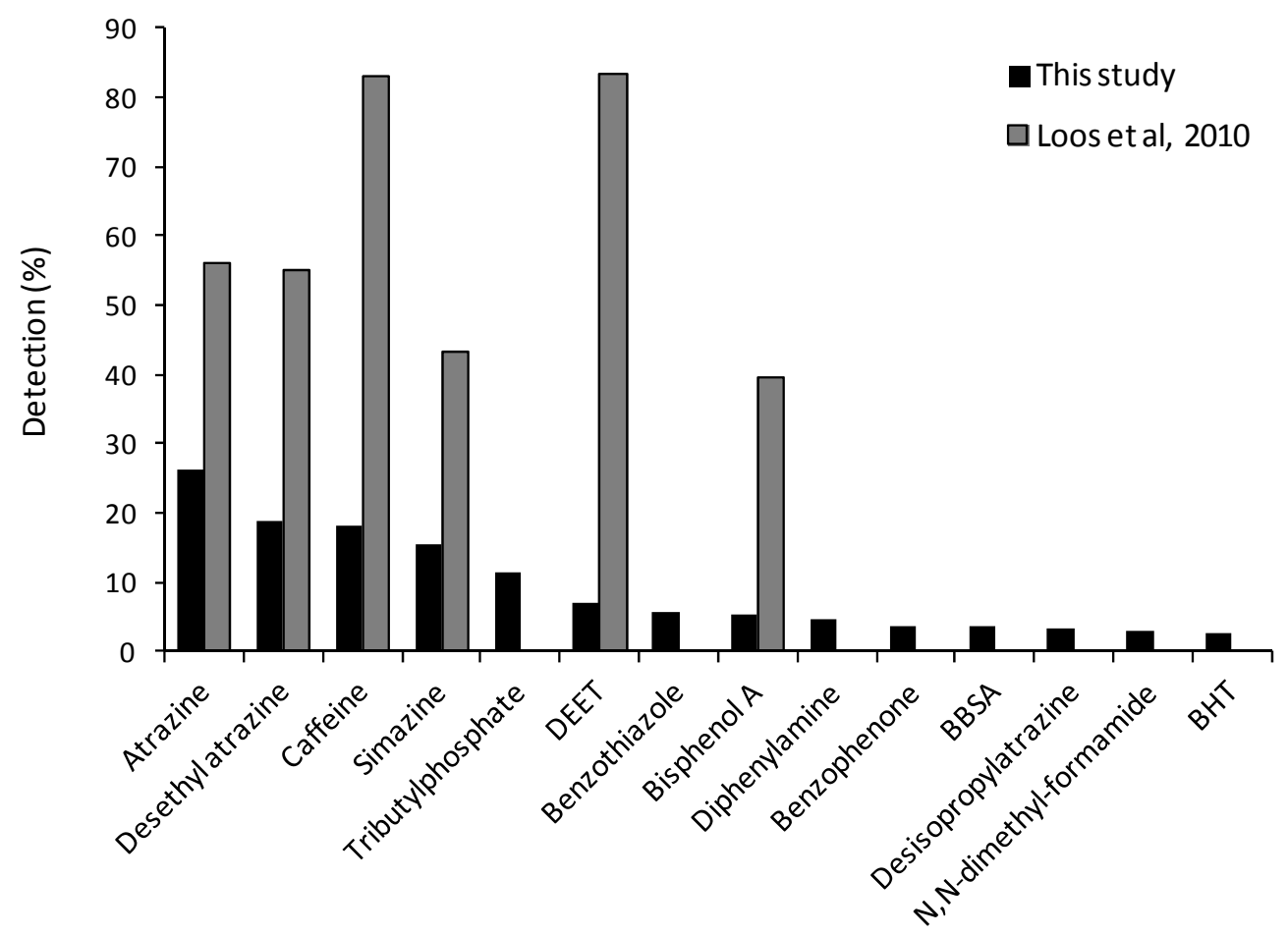

Figure 5 Top 15 polar compounds detected in England and Wales groundwater from this study compared with Loos et al 2010 


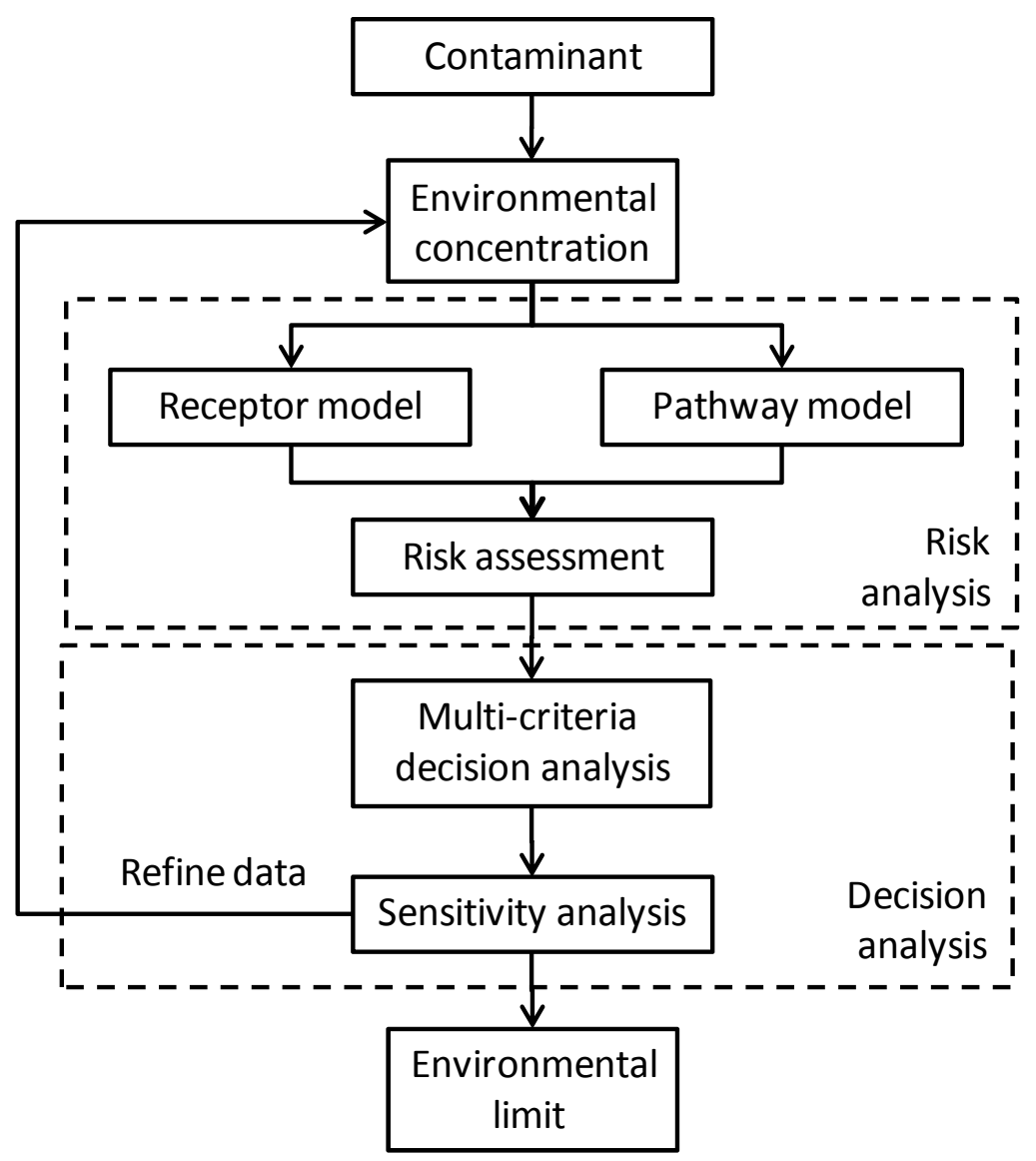

Figure $6 \quad$ Flow chart showing risk-based decision analysis (adapted from Khadam and Kaluarachchi, 2003) 